\title{
Arsāniyūs Shukrī al-Ḥakīm’s Account of His Journey to France, the Iberian Peninsula, and Italy (1748-1757) from Travel Journal to Edition*
}

\begin{abstract}
In 1748, the monk Arsāniyūs Shukrī al-Hakīm (1707-1786), a member of the Lebanese Maronite Order in Mount Lebanon, was sent to Catholic Europe, tasked with securing financial support and the protection of the French King for his indebted order. The literary byproduct of this journey through the Christian lands of Western Europe was an extensive travel account. Based on recent manuscript findings, the present contribution examines the different versions in which this ego-document has been transmitted, including the original travel journal written en route by Arsāniyūs himself, copies by contemporaries who turned the travel journal into a travelogue, an excerpt included in an anthology dating to the 1870 s, and finally the edition by the Jesuit scholar Ferdinand Taoutel (1887-1977). The account of the journey, it is argued, remained the object of a philological engagement that was meant to guarantee the continuity of its relevance and use in changing contexts.
\end{abstract}

\section{Keywords}

Travelogue, Arsāniyūs Shukrī, alms-collecting, Eastern Christianity, ego-documents, manuscripts, editing

\footnotetext{
* This article draws on research conducted for the project Stories of Survival: Recovering the Connected Histories of Eastern Christianity in the Early Modern World, which is supported by funding from the European Research Council (ERC) under the European Union's Horizon 2020 research and innovation programme (grant agreement number 638578).
} 


\section{Introduction}

The recent scholarly return to philology - "the discipline of making sense of texts" as Sheldon Pollock broadly defines $i^{1}$ - has shed light on the academic hegemony philology attained as it emerged as a discipline and was institutionalized in higher education in the West, a process that started in the late eighteenth and accelerated in the nineteenth century. ${ }^{2}$ Scholars have become increasingly aware of the necessity to question the inherent teleologies and eurocentrism of histories of philological engagement. Texts have always been sites of inquiry, even prior to philology reaching a scientific status, and communities across the globe have long grappled with care for their integrity and preservation. In response to the question "What was philology in Arabic in the early modern world?", the present contribution attempts to shed light on the vagaries of establishing, preserving, diffusing, transmitting, and generally making sense of one particular text: a travel account originally authored by the Maronite monk Arsāniyūs Shukrī (1707-1786), which covers his journey to France, Spain, Portugal, and Italy. By examining philological practices connected to the care for this text on a micro-historical scale, in their various epistemic contexts, over more than two hundred years, seemingly repetitive and secondary activities will emerge as constitutive of a subtle but continued work on the text. These activities involve copying, abridging, reformulating, excerpting and editing, among others.

Arsāniyūs came from a family of Armenian Christians who had switched rites and become members of the Maronite Church before the end of the seventeenth century. ${ }^{3}$ Insights into his life can be gleaned from an article written by the German Oriental scholar and traveler Ulrich Jasper Seetzen (1767-1811), who was fascinated with travel literature: Arsāniyūs was

\footnotetext{
${ }^{1}$ Sheldon Pollock, "Future Philology? The Fate of a Soft Science in a Hard World," Critical Inquiry 35 (2009): 934.

${ }^{2}$ Cf. Pollock, "Future," 936.

${ }^{3}$ Cf. Yūsuf Khaț̣̄ār Ghānim, Barnāmaj akhawiyyat al-qiddīs Mārūn, vol. 2 (Beirut: Al-Maṭba' al-kāthūlīkyya, 1903), 204.
} 
born as Jurjī b. Shukrī in Aleppo in $1707 .{ }^{4}$ As a young man, he was involved in trade and worked together with European merchants residing in the city. ${ }^{5}$ However, at the beginning of the 1740s, he joined the Lebanese Maronite Order in Mount Lebanon. ${ }^{6}$ Having advanced in the monastic hierarchy, in July 1748 he was sent by his indebted Order to Catholic Europe, tasked with securing financial support and French royal protection for the monks. Arsāniyūs consequently left the port of Beirut in October of the same year, ${ }^{7}$ departing for Marseilles in the company of the monk Baymīn (Poemen) b. Zakhariyya. As can be reconstructed from the travel account, the two gathered alms across France for several years. In May 1754, coming from French Bayonne, they arrived in Spanish Pamplona. This marked the beginning of a yearlong journey through the Iberian Peninsula that brought them in a circle back to Bayonne. Afterwards they concluded their journey in France and Italy. While travelling, Arsāniyūs was able successively to settle the order's debts from abroad and obtain a letter from the French King who extended his protection (himāya) to the order of Lebanese monks as well as a portrait of the king. Arsāniyūs finally returned to Beirut in summer 1757. After his return, he was appointed head of his Order and ordained Bishop of Aleppo in 1762 by Patriarch Ṭūbiyā al-

4 Cf. Ulrich Jasper Seetzen, "Nachrichten von einigen Arabischen, Persischen und Türkischen Reisebeschreibungen, Topographien und andern geographischen Werken und Landkarten,” Monatliche Correspondenz zur Beförderung der Erd- und Himmels-Kunde 12 (1805): 105.

${ }^{5}$ Cf. Seetzen, "Nachrichten," 105-106.

${ }^{6}$ Cf. Buṭrus Fahd, Tārīkh al-rahbāniyya al-lubnāniyya al-mārūniyya, vol. 5 (Jounieh: Mațābi' al-karīm al-ḥadītha, 1967), 29-30, and Seetzen, "Nachrichten," 106. The Lebanese Maronite Order had been created by three Maronites from Aleppo towards the end of the seventeenth century. The order took its name from Anthony the Great [Mār Anțūniyūs] (251-356).

${ }^{7}$ Cf. Seetzen, "Nachrichten," 106. 
Khāzin. ${ }^{8}$ When Ṭūbiyā died in 1766, Arsāniyūs found himself in an increasingly tense relation with the new Patriarch Yūsuf Istifān (1729-1793), due to financial conflicts and struggles brought about by inner divisions of the Maronite church. ${ }^{9}$ He died in 1786 under unclear circumstances in Kisrawan, where he had been forced to attend a synod. ${ }^{10}$

Arsāniyūs' literary achievements are few: he is known to be the author of a polemical work defending Mār Mārūn, the founding figure of the Maronite Church, against Melkite Catholics. ${ }^{11}$ It is not clear whether he wrote the history of his order that is also ascribed to him. ${ }^{12}$ As for the extensive account of his journey to the lands of the Christians, written in colloquial Arabic close to the spoken language, it could be summarized as an ethnography of the Catholic world, and France in particular. The travelogue describes churches, convents, and monasteries, such as the Igreja de São Roque in Lisbon. Moreover, food, customs, dress, processions, and urban daily life in France, Spain, Portugal, and Italy are described. Arsāniyūs also mentions technical inventions, for example clocks, and recounts historical events of consequence such as

\footnotetext{
${ }^{8}$ Cf. Seetzen, "Nachrichten," 108. Van Leeuwen observes that other parts of the Khāzin family opposed Arsāniyūs Shukrī's ordination due to the debts of his predecessor. Cf. Richard van Leeuwen, Notables and Clergy in Mount Lebanon: The Khāzin Sheikhs and the Maronite Church (1736-1840) (Leiden: Brill, 1994), 154.

${ }^{9}$ For a dispute regarding the tithe, see Bernard Heyberger, Hindiyya, Mystic and Criminal, 1720-1798: A Political and Religious Crisis in Lebanon (Cambridge: James Clarke \& Co, 2013), 126. Regarding the factions within the church see ibid., 125-127. Arsāniyūs later opposed the restoration of Yūsuf Istifān to the patriarchate in 1783. The latter had been temporarily deprived of his patriarchal faculties over the case of the nun Hindiyya. Cf. van Leeuwen, Notables, 138.

${ }^{10}$ Cf. Buțus Fahd, Bațārikat al-mawārina wa-asāqifatuhum: Al-qarn 18 (Beirut: Dār Laḥd Khātị, 1985), 448.

${ }^{11}$ Cf. Georg Graf, Geschichte der christlichen arabischen Literatur, vol. 3, Die Schriftsteller von der Mitte des 15. bis zum Ende des 19. Jahrhunderts: Melchiten, Maroniten (Vatican, Biblioteca Apostolica Vaticana, 1949), 466.

12 The manuscript mentioned by Graf, Geschichte, 3:466, can no longer be located. Another uncomplete manuscript in the Maronite Diocese (Ms. 1354) containing the "History" is not clearly attributed to Arsāniyūs.
} 
the execution of Robert-François Damiens (1715-1757) after the attempted assassination of the French King Louis XV (1710-1774) in 1757, and the beginning of the Seven Years' War. Besides daily life in Europe, he also sheds light on the royal courts of France and Spain, describing not only palaces and gardens, but also courtly protocol. All the while, he reflects on his activities as an alms-collector, and narrates his problems, experiences, and successes.

Arsāniyūs' travelogue is not only an ego-document, ${ }^{13}$ but can be considered to be an "open text" as well, to a certain degree. Such texts were by no means "completed" once the author had penned them, but they continued to be actualized and changed by later readers and copyists. In the Arabic tradition of travel writing, the travelogue written by Ibn Batțutta (1304$1368 / 9$ or 1377) has been shown to be such an "open text", as later copies demonstrate. ${ }^{14}$ In the openness of Arsāniyūs' travelogue lies the chance for an in-depth engagement with the philological practices through which it evolved and that were bound to and informed by the communal settings and social dynamics that gave rise to them.

To this day, the major reference for Arsāniyūs' travelogue is Ferdinand Taoutel's partial edition in the Arabic Journal Al-Mashriq, which appeared in 1967 and $1968 .{ }^{15}$ However, research in libraries has led me to uncover different unknown manuscript versions of the account. A small section of the original travel journal, written en route by Arsāniyūs himself,

\footnotetext{
${ }^{13}$ I adopt the broad definition of the term proposed in Ralf Elger, "Introduction," in Many Ways of Speaking about the Self: Middle Eastern Ego-Documents in Arabic, Persian, and Turkish (14 $4^{\text {th }}-20^{\text {th }}$ century), ed. Ralf Elger and Yavuz Köse (Wiesbaden: Harrassowitz, 2010), 8: "all texts with an ego talking about himself".

${ }^{14}$ Cf. Ralf Elger, "Die Reisen eines Reiseberichts_Ibn Baț̣utṭas Rihla im Vorderen Orient des 17. und 18. Jahrhunderts," in Buchkultur im Nahen Osten des 17. und 18. Jahrhunderts, ed. Tobias Heinzelmann and Henning Sievert (Bern: Peter Lang, 2010), 57-59.

${ }^{15}$ See Ferdinand Taoutel, ed., "Riḥlat al-ab Arsāniyūs Shukrī Ārūt̄in al-ḥakīm,” Al-Mashriq 61 (1967): 227-262; 325-356; 537-586; 62 (1968): 93-120.
} 
has been preserved in the Gotha Research Library. ${ }^{16}$ It only covers a couple of days, between 9 and 23 October 1753. Apart from the already known copy of the account in the Bibliothèque Orientale in Beirut that Taoutel used, ${ }^{17}$ another, probably earlier, copy of the text is located in Gotha. ${ }^{18}$ Both manuscripts contain a colophon that dates their completion to 1764 . It is, however, likely that the colophon was simply copied in the Beirut manuscript, as I shall argue in detail below. Extracts of the travelogue were later integrated into an anthology composed during the 1870s in Aleppo, which I was able to locate in the National Library in Cairo. ${ }^{19}$ The aforementioned textual witnesses, together with Taoutel's edition, represent the corpus for the following analysis.

A terminological note is in place here. Throughout this contribution, I shall distinguish between the text written by the author on a day-to-day basis and later copies of the same text, with their underlying literary pretensions, by referring to the travel journal on the one hand, and to the travelogue on the other. When discussing the abstracted idea of the text independent of its actualization, I shall address it as travel account. The anthology and edition of the travelogue will be referred to as such.

\footnotetext{
${ }^{16}$ Gotha, Ms. Orient. A 146, 13a-14b.

${ }^{17}$ BO, USJ 1764.

${ }^{18}$ Gotha, Ms. Orient. A 1549. Graf, Geschichte, 3:466, does not provide information about this copy of Arsāniyūs' account; it most probably did not see it himself because he only refers to Paul Sbath, Al-Fihris (Catalogue de Manuscrits Arabes), Deuxième Partie: Ouvrages des Auteurs des trois derniers siècles; Troisième Partie: Ouvrages Anonymes (Cairo: Al-Chark, 1939).

${ }^{19}$ Cairo, Tārīkh Taymūr 2041. I wish to thank Islam Dayeh for helping me acquire a digital version of the anthology. Graf, Geschichte, 3:466, alludes to the anthology by referring to a manuscript in Beirut that is likely lost; "Bairut 59" = Louis Cheikho, "Catalogue raisonné des manuscrits historiques de la Bibliothèque Orientale de l’Université St Joseph,” Mélanges de la Faculté Orientale 6 (1913): 248, no. 59.
} 
The present article is concerned with the contents of Arsāniyūs' rich travel account itself only to a limited degree. It focuses on the transmission history and the philological engagement with the text over a timespan of almost two hundred years. I argue that each of the different stages in the evolution of the text sheds light on knowledge formation in a particular historical setting. How did the text flourish in different early modern Arabic textual communities? What impact did these communities as loci of philological practices and methods have on the formation of the text? How did the different actualizations of the text themselves participate in intellectual and cultural dynamics? These are questions underlying the present contribution.

The travelogue was continually processed, rather than just written into existence at any single point in time. I shall argue that while the text was originally written to serve the very practical purposes of an alms-collector who needed to authenticate himself and document his journey, the earliest generation of copyists transformed it into a literary work meant to reach a new community of recipients fascinated with travelogues and the knowledge of the world they transmitted. This evolution was inaugurated by processes of abridgement and reformulation. It climaxed in a selection process that gave rise to the anthology into which excerpts of the text, bereft of the structuring narrative of the journey, were integrated. Arsāniyūs' text was finally established again in its integrity when the project of its edition was undertaken - against a background of the preservation of the Christian heritage and its past articulations. This final stage of textual evolution (for the time being, at least), represents an "after" in the encounter with European philological methods.

The author of the text, as well as copyists, anthologists, and editors who treated it, tried "to lift the material, linguistic, historical impediments to accessing and understanding" the travelogue and "to preserve the text in such a way as to guarantee the continuity of its relevance 
and use within a community of readers". ${ }^{20}$ Each time, the way the travelogue was preserved was different, each time, the community of readers was different.

Close readings and philological analysis shall be combined with a micro-historical approach in order to shed light on the continual reshaping of the travel account. Arsāniyūs is a fine example of a global actor and his account offers invaluable material for global history, given that he was an active participant in a global knowledge exchange along religious and economic networks. However, as a recent study of the traveler Elias of Babylon, who lived a century before Arsāniyūs has demonstrated, "the close study of a global life drags us back necessarily to a deep, local history". ${ }^{21}$ Studying the philological engagement with Arsāniyūs' travelogue over a longer time span also means coming to grips with the changing appropriation of global experiences and articulations in the local sphere.

\section{An alms-collector's travel journal}

The primary momentum for Arsāniyūs's journey was to gather donations for his debt-stricken Order. Since April 1748, Arsāniyūs had been the general administrator responsible for his monastery's finances. ${ }^{22}$ It was probably due to his trade connections with French merchants that, in July 1748, his superiors decided to send him to Catholic Europe, tasked with securing financial support for the order, and, ironically, to appease the order's French creditors by collecting from the French. What might also have played into the decision to send Arsāniyūs

\footnotetext{
${ }^{20}$ Islam Dayeh thus succinctly describes the tasks of philology in "The Potential of World Philology," Philological Encounters 1 (2016): 404.

${ }^{21}$ John-Paul Ghobrial, "The Secret Life of Elias of Babylon and the Uses of Global Microhistory," Past \& Present 222.1 (2014): 59.

${ }^{22}$ Cf. Buțrus Fahd, Tārīkh al-rahbāniyya al-lubnāniyya al-mārūniyya, vol. 4 (Jounieh: Mațābi al-karīm al-ḥadītha, 1966), 421.
} 
away, was a scandal that he had sparked by converting a Jew during one of his frequent visits to Aleppo, earlier in the same year. ${ }^{23}$

As for the Order's finances, an agreement between Arsāniyūs and those who had lent money to the order is documented; it is dated to 13 July $1748 .{ }^{24}$ The agreement was concluded in the house of the French Consul of Tripoli, by Arsāniyūs and some French merchants. A payment plan was drawn up: while the money lenders renounced interest, starting from January 1750 for the next seven years, the monks were supposed to pay back one seventh of their debts annually, their mills and olive groves serving as securities.

The travel account Arsāniyūs authored obviously came into being as a byproduct of a phenomenon that has been called somewhat anachronistically "financial tourism". ${ }^{25}$ From the first half of the eighteenth century on, an increasing number of Eastern Christians travelled to Western Europe asking for charity. This development is part of a broader pattern of Eastern Christian migration in the early modern world. ${ }^{26}$ Alms-collecting among monks, according to John-Paul Ghobrial, was a particularly “important expression of local practices of movement”.

\footnotetext{
${ }^{23}$ For this affair, see Būlus Qar'alī, “Al-Masīhịyyūn fī Ḥalab sanat 1748,” Al-Majalla al-baṭriyarkiyya 6 (1931). It seems that Arsāniyūs was arrested with other Maronite clerics. He was only released after twelve days, when his community paid a sum to the Ottoman authorities.

${ }^{24}$ See Lūwis Bulaybil, Tārīkh al-Rahbāniyya al-lubnāniyya al-mārūniyya, vol. 2 (Cairo: Maṭba'at Yūsuf Kawā, 1925), 94-96. He mentions a sum of 65.000 qurush. Cf. also Seetzen, "Nachrichten,” 105, on the agreement.

${ }^{25}$ Claus Heinrich Bill, “'Olivenprinzen’ im Deutschland der Frühen Neuzeit: Zwischen Morgenlandfaszination und religiöser Solidarität: Zum Finanzierungstourismus maronitischer mittelneuzeitlicher männlicher Libanesen 1750-1800," Nobilitas: Zeitschrift für deutsche Adelsforschung 24 (2002): 1186.

${ }^{26}$ See John-Paul A. Ghobrial, "Migration from Within and Without: In the Footsteps of Eastern Christians in the Early Modern World," Transactions of the Royal Historical Society 27 (2017), and Bernard Heyberger, "Chrétiens orientaux dans l'Europe catholique (XVII ${ }^{\mathrm{e}}-\mathrm{XVIII}{ }^{\mathrm{e}}$ siècles)," in Hommes de l'entre-deux: Parcours individuels et portraits de groupes sur la frontière de la Méditerranée XVI $-X X^{e}$ siècle, ed. id. and Chantal Verdeil, (Paris: Les Indes savantes, 2009), 61-92.
} 
In groups of two or three, monks were dispatched to a region to raise funds and hand them back to their institutions. ${ }^{27}$ Another group among the eighteenth century alms-collectors from the Levant that has barely been studied but has recently garnered scholarly interest were the socalled "Olive Princes" or "Arabian Princes", Maronites who asked for charity, presenting themselves as victims of religious persecution by the Turks. ${ }^{28}$ Later copies of Arsāniyūs' travelogue mention run-ins with these individuals. For example, Arsāniyūs heard about someone in Marseille who called himself the "Governor of Jerusalem" or "Pasha of Jerusalem". This person claimed to have been wronged by the Turks and to have been robbed of his wealth. Arsāniyūs was troubled by such "trickery" (حيله), which made his mission difficult and gave the Europeans reason for aversion towards Eastern alms collectors. ${ }^{29} \mathrm{He}$ resentfully remarks on the appearance of such individuals in Versailles during his own stay there and claims that he avoided contact with them. ${ }^{30}$

While collecting alms certainly constituted one among a number of intricate financial ties that connected East and West, it was also always simultaneously an activity that was bound to a set of textual practices. Journeys of alms-collectors began with paper trails: For purposes of self-authentication, a collector brought with him recommendations and letters emphasizing

\footnotetext{
${ }^{27}$ Cf. Ghobrial, "Migration,” 168-170; quotation ibid., 168. Nicolaus Möller, 1778), 459-464.

${ }^{29}$ Gotha, Ms. Orient. A 1549, 18 b (quotation); 29a.

${ }^{30}$ Gotha, Ms. Orient. A 1549, 38a-38b.
}

${ }^{28}$ For the "Olive Princes", see Bill, “Olivenprinzen," Ingeborg Titz-Matuszak, Mobilität der Armut: Das Almosenwesen im 17. und 18. Jahrhundert im südniedersächsischen Raum (Bovenden: Goltze, 1988), 164-168, Tobias P. Graf, “'Arabian Princes’: Performance and the Imagined Eastern Mediterranean in the EighteenthCentury Holy Roman Empire,” (in preparation), and Tobias Mörike, "Lebanese Travellers as Knowledge Brokers in Early Modern Europe 1725 to 1800" (in preparation). The traveler Carsten Niebuhr (1733-1815) devoted several pages of his Reisebeschreibung to the Arabian Princes from Lebanon. See Carsten Niebuhr, C. Niebuhrs Reisebeschreibung nach Arabien und andern umliegenden Ländern, vol. 2 (Kopenhagen: Hofbuchdruckerey bei 
his honorable background. In Rome and imperial cities, recommendations and passports were procured. ${ }^{31}$ Arsāniyūs reports for Spain that the Maronite Miguel Casiri (1710-1791), who was born in Tripoli, had studied in Rome and was then employed in the Royal Library in Madrid, was responsible for checking the documents of all Oriental alms collectors in Spain, before issuing permits. ${ }^{32}$ Letters continued to play a role during the journey; notably in difficult circumstances in the form of petitions. For example, Arsāniyūs was arrested in Orléans both because he violated an ordinance by the French king regulating the activities of almscollectors, ${ }^{33}$ and because he had failed to pay off debts to his order's creditors, payable to their representatives in Marseilles. He was consequently brought from Orléans to Paris. Only letters and petitions to the queen saved him from incarceration. ${ }^{34}$

Besides official letters, monastic travelers needed to authenticate themselves by presenting a book with their monastic rules, as Arsāniyūs mentions. In Spain, he reported that monks from another order had misused the book of his own order (كتاب قانوننا), which caused him trouble. ${ }^{35}$

Above all, alms-collectors were expected to document their journey and to account for their expenses and income in written form. ${ }^{36}$ It is in this respect that alms-collecting had a literary dimension, ushered in a set of philological practices and provided an impulse for self-

\footnotetext{
${ }^{31}$ Cf. Bill, “Olivenprinzen,” 1193-1196. Cf. the comments in Niebuhr, Reisebeschreibung, 2:459-460.

${ }^{32}$ Gotha, Ms. Orient. A 1549, 164a.

${ }^{33}$ Gotha, Ms. Orient. A 1549, 127b-128b, mentions the edict and offers a translation. For the original edict, see Louis XV, Ordonnance du Roi portant ce qui devra être observé par rapport aux Maronites \& autres Chrétiens orientaux, \& aux Esclaves rachetés qui se trouveront dans le royaume (Paris: Imprimerie Royale, 1753).

${ }^{34}$ On the entire episode, see Gotha, Ms. Orient. A 1549, 128b-131a. Cf. Seetzen, "Nachrichten,” 108.

${ }^{35}$ Gotha, Ms. Orient. A 1549, 163 b.

${ }^{36}$ On the importance of alms-collectors' notebooks and cashbooks, cf. the comments by Ghobrial, "Migration," 168.
} 
authorship. In a section of his Reisebeschreibung that the traveler Carsten Niebuhr (1733-1815) devotes to the Arabian princes, he mentions "the diary, or rather the travel itinerary and the account of revenues and expenditures" they authored. ${ }^{37}$ They passed along information, such as "the names of towns that they visit, the coins used in each country, the alms they have received, the taverns where someone paid for them, what they had to pay to customs agents or as gratuities or for their sustenance". ${ }^{38}$

Four pages of such a diary, or travel journal, which constitute one bi-folio (مجلد), have been preserved in Arsāniyūs' case in a collection of loose manuscript pages in Gotha. ${ }^{39}$ These four pages are invaluable as they allow for the reconstruction of the authorial process on the journey. Arsāniyūs' journal was written on a day-to-day basis. The last sentence of the surviving bi-folio (see figure 1), which precedes a number of localities indicated in French, implies an ongoing process of writing:

We are, God willing, going to talk about Tours in the next bi-folio (مجلد), about the beauty of its buildings and its wealth. Completed on 19 November $1753 .^{40}$

\section{Figure 1}

Figure 1: Page from a surviving bi-folio of Arsāniyūs Shukrī’s travel journal, written during his journey from 1748 to 1757 . The entry is dated to 19 November 1753. A list of distances between French cities follows in French at the bottom of the page. The city name of Shatirlū (Châtellerault, misspelled in the list of distances as Chaterlles)

\footnotetext{
${ }^{37}$ Niebuhr, Reisebeschreibung, 2:460.

${ }^{38}$ Niebuhr, Reisebeschreibung, 2:460. Cf. also Bill, “Olivenprinzen,” 1203.

${ }^{39}$ Gotha, Ms. Orient. A 146. The untitled collection comprises parts of different manuscripts and individual papers without a common theme.

${ }^{40}$ Gotha, Ms. Orient. A. 146, 14b.
} 
is indicated in Arabic on the right margin. The bi-folio has been preserved within a collection of loose manuscript pages. Gotha Research Library, Ms. Orient. A 146, folio 14b.

For obvious reasons, this remark, which might have allowed Arsāniyūs to keep his notes in order by offering a connection to the next bi-folio, or might have reminded him of what was supposed to be reported next, did not make it into later versions of the travelogue. Both the Gotha and the Beirut copies simply move on to the description of the city of Tours. ${ }^{41}$

Besides keeping a travel journal, Arsāniyūs was supposed to list the exact sums collected and spent in a cash booklet. Although it has not been preserved, Arsāniyūs possessed such a booklet; he describes it himself:

The booklet $($ فن (ف) is written in the French language and expense after expense is written down without changes. [It contains] everything we gathered in France while collecting alms (شحاماه), everything we gave back to the French people (طايفة الفرنساويه) payment after payment, and everything we spent in the last three and a half years, for us, our journey, our horses, food, drinks, accommodation, etc. ${ }^{42}$

The travel journal of a contemporary (unfortunately unnamed) Christian alms-collector shares characteristics with Arsāniyūs' journal and simultaneously sheds light on what the lost cash booklet might have looked like. ${ }^{43}$ (See figure 2.)

\footnotetext{
${ }^{41}$ Gotha, Ms. Orient. A 1549, 123b; BO, USJ 1764, 94b.

${ }^{42}$ Gotha, Ms. Orient. A 1549,129 b.

${ }^{43}$ Chur, Ms. B-14. See Monika Winet, "Religious Education on the Road: An Anonymous Christian Arabic Diary," Parole de l'Orient 39 (2014), for a description of the manuscript, of which she currently prepares a critical edition. The following information in the manuscript is derived from her article.
} 


\section{Figure 2}

Figure 2: Two pages from a travel journal written by an anonymous alms-collector between 1745 and 1750 ; the entries are assigned dates between 22 July 1746 and 3 August 1746 on the margins. The city name of Sārākūsā (Saragossa) is indicated to the right of the first of these entries. Three lists of convents, outside of the walls, inside the city, and convents for nuns, are inserted in Italian with Arabic captions. Chur, Cantonal Archives of Graubünden, Ms. B-14, folio 19b-20a.

The journal in question, which was written on bi-folios in Arabic script and in Karshūnī, covers the time span between 7 September 1745 and 24 January 1750 and contains, apart from the account of the journey, a cash booklet (or rather two booklets: one for expenses, one for income). ${ }^{44}$ Its author identifies himself as a bishop, who travelled with a companion. ${ }^{45}$ His journey led him from Rome through Italy and France to Spain, whence he returned to Italy. Like Arsāniyūs, the author was on a mission to secure financial support for his community. ${ }^{46}$ The fact that the cashbook with the expenses finishes two years earlier than the journey itself and the cashbook with the income one and a half years earlier, might indicate that the three booklets were originally independent. ${ }^{47}$

Another travel journal - this one without cashbook - that has been preserved was written by the Melkite Catholic monks Yuhannā Naqqāsh and Tūma Kurbāj, from the Basilian Order of Mār Yūḥannā in Shuwayr. ${ }^{48}$ From Mount Lebanon, they were sent to Western Europe. ${ }^{49}$ The

\footnotetext{
${ }^{44}$ For a structural overview of the manuscript, see Winet, "Religious Education,” 302.

${ }^{45}$ Cf. Winet, "Religious Education," 302-303.

${ }^{46}$ Cf. Winet, "Religious Education," 297.

${ }^{47}$ Winet, "Religious Education,” 302, alludes to this possibility.

${ }^{48}$ The booklet has been described by Michel Abras, "Le Voyage de deux moines melkites en Italie du Nord en 1775," in Les Européens vus par les Libanais à l'époque ottomane, ed. Bernard Heyberger and Carsten-Michael Walbiner (Beirut: Ergon, 2002).

${ }^{49}$ Cf. Abras, "Le Voyage," 59.
} 
text covers the journey they undertook through Northern Italy from 1775 to 1777 in order to collect alms.$^{50}$ Finally, the last known account written by Eastern Christians who gathered alms was penned almost a century later. From 1850 to 1855, the Melkite priests Mūsā Muqaḥhat and Fīlibūs Numayr travelled through France and the Austro-Hungarian Empire, gathering alms for the building project of a Melkite cathedral in Zahla. The account was written by Numayr. ${ }^{51}$ No cashbook has survived in this case either.

The initial composition of a travel journal and the activities and interests of the almscollectors were interrelated. All the accounts mentioned above offer extensive descriptions of churches, monasteries, convents and Christian communities, interwoven with numerous observations on everyday life, manners and customs, dress, food and celebrations. In Arsāniyūs' account, as it has been preserved in later copies, the issue of collecting alms comes up time and again. It structures the narrative, holding it back when Arsāniyūs was faced with obstacles and problems; generosity or a lack thereof influenced his perception of a town's or village's inhabitants and had a decisive impact on his assessment and appraisal of what he observed. The links between the collection of alms, travelling, self-authorship and knowledge formation are undeniable in this first version of the travelogue. Eighteenth-century Lebanese travelers with financial motives functioned as "knowledge brokers". On the one hand, Europeans were able to learn in their encounters with the travelling alms-collectors. The Arabian princes even figured as personae in Enlightenment literature. ${ }^{52}$ Conversely, knowledge was also transmitted among the Maronites via the written travel journal, most importantly knowledge of the European courts, the composition of European style letters, geographical and political information, which

\footnotetext{
${ }^{50}$ Cf. Abras, "Le Voyage," 59, on the charity aspect of the journey.

${ }^{51}$ American University of Beirut, Ms. 735, Ms. 976 (in two volumes, entitled Irtiḥālat al-khūrī Mūsā Muqaḥhat wa-l-khūrī Fülibūs Numayr ilā al-Urūbāa).

${ }^{52}$ For the notion of knowledge brokers, see Mörike, "Lebanese Travellers."
} 
was an important prerequisite for successfully asking for charity in Catholic Europe. ${ }^{53}$ The aforementioned observations on the first version of Arsāniyūs' travelogue tally with these findings. In its initial stage, Arsāniyūs' account was a travel journal that documented his activities as an alms-collector. Together with information about the financial tour, much more "raw knowledge" of the world was passed along to potential audiences at home.

Interestingly, the financial dimension of Arsāniyūs' travel narrative links it with earlier travelogues by Christian travelers whose journeys were, at least to a certain degree, financially motivated, but eventually paved the way for knowledge transmission about the world. The famous Riḥlat al-Bațriyark Makāriyūs al-Halabī ("Travels of the Patriach Makāriyūs from Aleppo"), an account of the journey of the Patriarch Makāriyūs b. al-Za '̄im (ca. 1600-1672) to Moscow, written by his son Būlus (Paul of Aleppo, 1627-1669), is a case in point. ${ }^{54}$ From 1652 to 1659 , the Patriarch travelled through Moldavia, Walachia and Ukraine to Russia in order to collect alms for his indebted community among the Orthodox. Būlus meanwhile not only wrote about the churches visited, the masses celebrated and the icons seen, but also about customs, fauna, dress and historical events. While the author of yet another major early travelogue, the Chaldean Catholic Ilyās al-Mawșilī (d. c. 1700), does not explicitly refer to his having left Baghdad for the purpose of collecting alms, the itinerary of the journey reflects the popular routes taken by alms collectors and the collection of donations is mentioned throughout the journey. ${ }^{55}$ Departing from Baghdad in 1668, Ilyās travelled to Rome and visited the courts in France, Italy and Spain, before travelling to the Spanish colonies in Central and South America. He only returned to Western Europe in 1683 . The travelogue along with the associated history

\footnotetext{
${ }^{53}$ Cf. Bill, "Olivenprinzen,” 1200; 1203.

${ }^{54}$ On the travelogue, see Hilary Kilpatrick, "Makāriyūs Ibn al-Za '̄ìm (ca. 1600-1672) and Būlus Ibn al-Za'īm (Paul of Aleppo) (1627-1669)," in Essays in Arabic Literary Biography 1350-1850, ed. Joseph E. Lowry and Devin J. Stewart (Wiesbaden: Harrassowitz, 2009), 269-272.

${ }^{55}$ Cf. Ghobrial, "The Secret Life," 62-64.
} 
of the Americas, has been called "a celebration of the spread and triumph of Christianity." 56 The work, which was influenced by beliefs of the Church of the East, contains fictional elements but it also transmits knowledge from Spanish traditions of writing. Both the accounts of Makāriyūs' and of Ilyās al-Mawșilī’s journeys have been classified as “Accounts of Journeys to Request Positions or Financial Support". ${ }^{57}$ At the same time, they bear witness to the "mobility, diversity and creativity within Ottoman culture". ${ }^{58}$ While the impetus for these travel accounts was the collection of alms, the resulting accounts distinguished themselves by the vast horizons of knowledge about the world they transmitted.

\section{From travel journal to travelogue}

Arsāniyūs' account of his journey encountered vivid interest among contemporaries. It was copied repeatedly in the decades after his sojourn in Catholic Europe. In the framework of this engagement with the travelogue, a disjunction between the very practical purpose of the journey and its literary output occurred. The nexus between alms collector and author was dissolved. The travel journal became a travelogue; it became self-sufficient in a way it never had been before. It lived on as a literary project that continued to take shape through the hand of its copyists.

\footnotetext{
${ }^{56}$ Ghobrial, "The Secret Life,” 71.

${ }^{57}$ See Hilary Kilpatrick, "Between Ibn Baț̣̂uța and al-Ṭahțāwī: Arabic Travel Accounts of the Early Modern Period," Middle Eastern Literatures 11 (2008), 240-241. For a study of four Muslim careerists' travelogues composed in the sixteenth and seventeenth centuries, see Ralf Elger, Glaube, Skepsis, Poesie: Arabische IstanbulReisende im 16. und 17. Jahrhundert (Beirut: Orient-Institut, 2011).

${ }^{58}$ Kilpatrick, "Between Ibn Baț̣tūṭa and al-Ṭahțāwī̄," 245.
} 
One of the earliest copies of Arsāniyūs' account, if not the earliest copy altogether, is currently preserved in the Gotha Research Library. ${ }^{59}$ It was purchased by Ulrich Jasper Seetzen in Aleppo between 1803 and 1805. The latter commented on his purchase as follows:

The exemplar which is now available in the Oriental Collection in Gotha was written by his brother $[\ldots]$, and it is probable that the Bishop shared his brouillon, which no longer exists, with the abovementioned [i.e. the brother]. [...] I bought the book from the sons [of the latter], who only paid attention to the events, and cared little for literary things. Although a copy was hastily made, it remained unfinished due to lack of time. ${ }^{60}$

This suggests that Seetzen believed his copy to be the only one written by Arsāniyūs' brother Hannā (d. 1775), and the only complete one at that. This might be an erroneous assumption on Seetzen's part, since we cannot exclude the existence of earlier manuscript copies. (See below on the anthology.) Besides the Gotha manuscript, we know of at least two other copies of the travelogue, which Ferdinand Taoutel used in his edition, to which I shall return later. The Maronite priest Jurjus Manash (1873-1931) from Aleppo initially owned these two manuscripts; one of the manuscripts entered the possession of Najīb Mukarbana around 1941. In 1956, Mukarbana gave it to Taoutel in exchange for a new book by the latter, Al-Munjid fi $l$ lugha wa-l-adab wa-l- 'ulüm ("Savior in Language, Literature and the Sciences", a reprint and sequel to Lūwīs Ma 'ūf's 1908 Al-Munjid fì l-lugha, "Savior in Language”). ${ }^{61}$ Taoutel described the manuscript extensively in the introduction to his edition of the travelogue. ${ }^{62}$ This manuscript

\footnotetext{
${ }^{59}$ Gotha, Ms. Orient. A 1549.

${ }^{60}$ Seetzen, "Nachrichten," 108-109. My translation.

${ }^{61} \mathrm{BO}, \mathrm{USJ}$ 1764, marginal note on the inside of the cover.

${ }^{62}$ Taoutel, "Riḥlat al-ab Arsāniyūs,” 227.
} 
is today preserved in the Bibliothèque Orientale of the Université Saint-Joseph Beirut and it has recently been digitized by HMML. ${ }^{63}$ The second Manash manuscript was later owned by the Maronite (and later Orthodox) priest Ilyās al-Ghālī (1895-1970), who gave Taoutel access to the manuscript. While Taoutel did not describe this copy in the introduction to his edition, he made notes on loose pages regarding two missing folios from the Manash-Mukarbana manuscript; these notes have been preserved with the Manash-Mukarbana manuscript and were digitized by the Hill Museum and Manuscript Library (HMML) as well. ${ }^{64}$ According to these hastily written scribbles, the copyist of the Manash-al-Ghālī manuscript was Rizq Allāh b. Luwīs (?) Anțūn Hakīm. ${ }^{65}$ The fate of the Manash-al-Ghālī manuscript is unknown. ${ }^{66}$ Several other copies of the travelogue mentioned en passant might be different copies, or they might correspond to the two Manash manuscripts. The first reference comes from marginalia in the Manash-Mukarbana manuscript. A certain Mr. Sallūm seems to have owned another copy of the travelogue ${ }^{67}$ This might, or might not, be a reference to another owner of the Manash-alGhālī manuscript. Another hint at manuscript copies of the travelogue comes from Paul Sbath. In his Al-Fihris, he also mentions two manuscripts of the travelogue, although like all the other

\footnotetext{
${ }^{63}$ BO, USJ 1764. HMML, reading room: https://www.vhmml.org/readingRoom/view/129738.

${ }^{64}$ BO, USJ 1764, loose papers with notes in Taoutel's handwriting (scanned by HMML at the end of the manuscript)

${ }^{65}$ The notes also contain the colophon of the Manash-al-Ghālī manuscript. The year Taoutel indicated for the copy is not clear, but probably 1767 . If the date is correct, Seetzen was obviously not aware of additional copies circulating besides the one he acquired.

${ }^{66}$ The existence of the two Manash manuscripts was independently corroborated by Louis Cheikho, who mentioned in 1923 two versions of Arsāniyūs' travelogue in the library of Jurjus Manash. Cf. Louis Cheikho, Kitāb al-Makhțūtāt al-'arabiyya li-katabat al-nașrāniyya (Beirut: Imprimerie Catholique, 2000 [reprint of the 1924 edition]), 125 .

${ }^{67} \mathrm{BO}$, USJ 1764, back of the cover.
} 
manuscripts listed in this work, none of them can be located. ${ }^{68}$ These two manuscripts belonged to the families of Mīkhā' îl 'Abdīnī and Anțūn Mațar. They could correspond to the Manash manuscripts, or be a different pair of manuscripts.

Although at present only two manuscript copies of the travelogue can be located (in Gotha and Beirut), a wider circulation of it is probable. This afterlife of Arsāniyūs' original account is a symptom of an increasing preoccupation with travel literature in Arsāniyūs' milieu, and ongoing work on the account conducted by copyists, as shall be shown below.

According to the colophon, which appears both in the manuscripts in Gotha and Beirut, Arsāniyūs' brother Ḥannā al-Ṭabīb copied the manuscript (the colophon thus lending credibility to Seetzen's statement quoted above):

The most humble servant, the poor Hannā, the physician, also called shammās, the son of Shukrī, brother of Father Arsāniyūs, who ventured on this journey and is nowadays Bishop of the Maronites in the city of Aleppo, wrote or rather copied [this travelogue]. May God grant him to live long and continue to guide us spiritually and make obedience to him lie light on us. This [was written] in the year 1764, on the thirtieth day of the month of May. ${ }^{69}$

It is probable that the Beirut manuscript is a copy of Hannā's version (including the colophon) by another copyist who also modified the text significantly. It is unclear who this second copyist

\footnotetext{
${ }^{68}$ Cf. Sbath, Al-Fihris, 48.

${ }^{69}$ Gotha, Ms. Orient. A 1549, 215a. Cf. BO, USJ 1764, 194a.

"قد كتبه بل سوهـ احقر العباّا الفقير حنا باسم شماس الطبيب ابن شكري اخو الاب ارسانيوس صاحب هذه الرحله الذي يومها مطر ان الموارنه بمدينة حلب الام الله حياته و ابد علينا حكومته وسهل لدينا طاعته وذلك بتاريخ سنه 1764 مسيحيه في اليوم الثلاثون من شهر ايار."
} 
was. Seetzen's recollections, however, point to one of Ḥannā’s sons, perhaps Ilyās, because his name appears in ownership statements in both manuscripts. ${ }^{70}$

Both Hannā and the copyist of the Beirut manuscript not only copied the travel journal, but continued working on the text. Changes between the different copies shed light on the nature of this "work on the text". Assuming that the Gotha manuscript was based on the original travel journal, the copy can best be compared to the four preserved pages of the journal - although one has to bear in mind that the surviving four pages quantitatively represent less than one percent of the total length of the Gotha account, with its 221 folios or 442 pages.

Hannā's changes were above all of a stylistic nature; he improved the traveler's sometimes garbled sentences. For example, "the Bishop of this city was an old man, close to ومطر ان هذه المدينه رصل اختيار قريب ( seventy years of age, but beloved and of curteous conduct" سبعون سنه عمره لكن محبوب وصاحب سيره مكلفه (س) ${ }^{71}$ was improved to “and this bishop was an old man, وهذا (approaching seventy years of age, but he was beloved by all and a man of saintly conduct” (المطر ان رطل اختيار عمره نحو سبعين سنه لكنه محبوب من الجميع وذو سيره مقدسه are further developed in conjunction with such stylistic changes. The presentation of the people of Angoulême in the travel journal, "the people of this city are friendly and very Christian, very few heretics are there" (اهل هذه المدينه انيسين وقوي مسيحيه قليل \داً يو \د فيها ار اطقه), Ḥannā as follows: "the people of this city are friendly and affectionate; they are Christian people; only very few heretics live among them and they are not overtly so" ( ول هذه المدينه فيهم (اناسه ومحبه وهم اناس مسيحيين ويولد ما بينهم بعض ار اطقه الا قليلين و غير ظاهرين the linguistic fabric of the account and adding to its thematic poignancy, Hannā further

\footnotetext{
${ }^{70}$ Gotha, Ms. Orient. A 1549, 221a; BO, USJ 1764, 198 b.

${ }^{71}$ Gotha, Ms. Orient. A 146, 13a.

${ }^{72}$ Gotha, Ms. Orient. A 1549, 120 b.

${ }^{73}$ Gotha, Ms. Orient. A 146, $13 a$.

${ }^{74}$ Gotha, Ms. Orient. A 1549, $121 \mathrm{a}$.
} 
improves on the readability of the account by transliterating or avoiding French toponyms which Arsāniyūs used in his travel journal. For example, the city of Périgueux appears in the margin of the travel journal in Latin letters (without accent, however). ${ }^{75}$ Hanna transliterates it as بيريكوه, using the Persian letter $p e .{ }^{76}$ Similar examples could be adduced. ${ }^{77}$ Finally, an index was presumably added to the travel account. ${ }^{78}$ This index with the rhyming title "Index of what is in this book and God leads to what is right” (فهرسة ما بهذا الكتاب و الله المهدي الي الصواب) - in many ways a peculiarity ${ }^{79}$ - was certainly added by Ḥannā, given that his own travelogue (on which further below) was also furnished with an index. The index in Hannā's copy of Arsāniyūs' travel account presents themes, toponyms, events etc. referred to on the margins of the main text in alphabetical order, and indicates the corresponding page number, e.g. "Garden of Versailles" (بستان ورساليه) under the letter $b \bar{a}$ ', or "Burning of the Sultan of France's stables"

\footnotetext{
${ }^{75}$ Gotha, Ms. Orient. A 146, 13a.

${ }^{76}$ Gotha, Ms. Orient. A 1549, 121a.

${ }^{77}$ Another example is Ligueux, which is mentioned in Gotha, Ms. Orient. A 146, 13b. Gotha, Ms. Orient. A 1549 , 121b, deletes the French city name and replaces it with “The places of idol worship” (معابد الاصنام).

${ }^{78}$ Gotha, Ms. Orient. A 1549, 217a -221a.

${ }^{79}$ Indexes were not generally unknown to the Arabic manuscript tradition. See Franz Rosenthal, The Technique
} and Approach of Muslim Scholarship (Rome: Pontificium Institutum Biblicum, 1947), 40, who mentions Najm alDīn b. Fahd's (d. 1480) index works. On information management in the Arabic-Islamic tradition, see also Ann M. Blair, Too Much to Know: Managing Scholarly Information before the Modern Age (New Haven: Yale University Press, 2010), 24-28. She mentions ibid., 25, alphabetical manuscript indexing in hadīth collections. In the Latin West, printed indexes were more abundant than manuscript indexes and became a common tool only with printing, but there, too, alphabetical indexing did not first appear with printing. Cf. notably ibid., 46-55. It is very probable, however, that the index in Arsāniyūs' travelogue - for lack of a more suitable term entitled fihrist "table of contents" - was influenced by printed indexes, because reference is made to page numbers instead of textual units; they are also included in the work itself and not produced separately - all characteristics of printed indexes (cf. ibid., 144). 
under the letter $h \bar{a}^{\prime}$. This, too, certainly increased the accessibility of the text for its readers.

The copyist of the Beirut manuscript (perhaps the hasty copy to which Seetzen referred), maybe Ḥannā's son Ilyās, continued in the same vein as his father, but went further with his work on the text. He strove for even greater simplicity. His transcription of the toponym Périgueux dispenses with the Persian letter and becomes Bīrīkūh. ${ }^{80}$ His description of the bishop mentioned above is broken down to "and he is a man of seventy years" (وهو رصل ابن سبعون سنه); the rest is omitted ${ }^{81}$ This latter change points to a strong tendency to abridge and condense the travel account. Numerous omissions and abbreviated passages can be identified. Places for these changes are more often than not extensive descriptions of churches and monasteries Arsāniyūs visited on his journey. For example, the copyist excluded the descriptions of convents in the area of Aumale $;^{82}$ he also deleted the extensive description of the admission ceremony for two monks and the description of a Carthusian monastery. ${ }^{83}$ Interestingly, when omitting the entire passage covering Arsāniyūs' journey from Aumale to Trappes, the copyist finally reflects on his modifications, assuming the voice of the narrator, "we then travelled to a number of cities but we abstained from mentioning them for reasons of length (لإلهوله).84 This abridgement must have been made by the copyist of the Beirut manuscript since the Gotha manuscript preserves the longer (original) version, which includes the omitted part, and it would be even less likely for Hannā to have created and inserted this part than for the present copyist to have omitted it. That the latter assumes the voice of the narrator in order to do so is certainly exceptional.

\footnotetext{
${ }^{80} \mathrm{BO}$, USJ $1764,92 \mathrm{~b}$.

${ }^{81} \mathrm{BO}$, USJ 1764, 92a.

${ }^{82}$ Gotha, Ms. Orient. A 1549, 78a; cf. BO, USJ 1764, 72 b.

${ }^{83}$ Gotha, Ms. Orient. A 1549, 78b-80a; cf. BO, USJ 1764, $72 b$.

${ }^{84} \mathrm{BO}$, USJ 1764, $72 \mathrm{~b}$.
} 
Another example is the description of the Jesuit College at La Flèche, which is shortened significantly. Again, the copyist inserts a short statement, "We cannot describe the constructions and the beautiful things because we want to make it short (رغبةً بالاقتصار)"85." Obviously, the copyist strove for a more condensed, less repetitive, more stringent version of the account. He therefore was forced to renounce observations made by a traveler whose primary focus was the domain of the church: church buildings, religious ceremonies and rituals, monastic communities and similar matters. One possible reason for abridging the original text may be sought in the implicit reader. The readership for which the copies were produced was not one of monks that were potential alms-collectors themselves. This new readership was not interested in tracing Arsāniyūs' exact movements, in the detailed itinerary of his journey, including each small Catholic community encountered on the way. It was much more interested in the knowledge of the world - notably ethnographic knowledge - imparted by Arsāniyūs. Interestingly, book abridgement was a ubiquitous technique in eighteenth-century Europe. Long dismissed as a "parasitic" secondary activity, a recent study has demonstrated its important socio-cultural function in England ${ }^{86}$ While such techniques have not yet been studied in the milieu under investigation, it is reasonable to assume that motives are comparable. Abridgments reduced the time that needed to be invested in literary consumption by expediting the process of reading and adapted the text to the tastes of diverse audiences, thus furthering the dissemination of knowledge. We shall see that the process inaugurated through rather subtle deletions in the copies would later climax in the anthology, in which references to the original purpose of the journey and its itinerary were crossed out almost entirely.

\footnotetext{
${ }^{85}$ Gotha, Ms. Orient. A 1549, 114a-115a; cf. BO, USJ 1764, 89b-90a.

${ }^{86}$ See Jordan Howell, "Book Abridgment in Eighteenth-Century England” (unpublished PhD diss, University of Delaware, 2017).
} 
Besides the subtle changes on the main text, it is interesting to note that the index evolved in the Beirut copy of the manuscript, too. On the one hand, it became more systematic. For example, in Hannā's copy of the travel account, the index words and phrases under the letter $k h \bar{a}^{\prime}$ are not presented strictly in ascending order; a reference to page 423 is followed by a reference to page $2 .{ }^{87}$ Such flaws are smoothed out in the Beirut manuscript. ${ }^{88}$ On the other hand, the index is also adjusted to the copyist's abridgments. The Carthusian monastery in Aumale, which is indexed twice in the Gotha manuscript, does not appear in the Beirut index, where it is deleted from the text, as has been shown. ${ }^{89}$ This evolution points to a greater systematization of the knowledge presented in the text and a work on its accessibility.

The travel account, at this point, had acquired a certain independence from its author. No longer a travel journal, it had become a travelogue..$^{90}$ The copyists transformed a diary-like text authored by an alms-collector on a day-to-day basis, with which he intended to authenticate himself and to carefully document his trip, written on the go in sometimes garbled sentences, into a stylistically more refined account that dispensed with tedious passages on the itinerary and monastic infrastructure. Its colloquial character was kept intact for the same reason that foreign words were arabized: in order to speak to a public fascinated with knowledge of the

\footnotetext{
${ }^{87}$ Gotha, Ms. Orient. A 1549, 218 b.

${ }^{88}$ BO, USJ 1764, 196a.

${ }^{89}$ Gotha, Ms. Orient. A 1549, 217a and 218b (under alif and under $r \bar{a}$ ).

${ }^{90}$ Evidence for even further changes is provided by Taoutel's notes on the Manash-al-Ghālī manuscript, in particular by his copy of the folio covering the execution of Damiens which is missing in the Manash-Mukarbana copy. When talking about the event, in the Gotha copy Arsāniyūs only reports having heard about the execution; according to Taoutel's notes, in the Manash-al-Ghālī manuscript, Arsāniyūs mentions that he stood "beside the queen". This probably points to a certain dramatization, which would be interesting given the early date of the Manash-al-Ghālī copy.
} 
world that was channeled into travelogues. Systematic indexing made bits of information provided in the text easily accessible.

In order to understand the philological practices of copyists from Arsāniyūs' own generation and the following one, it is necessary to consider the context of their activities. The copies of Arsāniyūs' account were created in a milieu in which travelogues were authored, copied, translated and widely appreciated. The genre experienced a veritable boom in mideighteenth-century Aleppo. ${ }^{91}$ Starting with Arsāniyūs' immediate relations, his abovementioned brother, the physician Hannā, was a traveler and author of a travelogue. It has been preserved, albeit virtually forgotten, in the Gotha Research Library. ${ }^{92}$ The text is a lengthy narrative in colloquial Arabic, strongly characterized by a multitude of Ottoman loan words. Hannā narrates that he was ordered to Istanbul by the Grand vizier to treat the şeyhülislam. While travelling from October 1764 to May 1765, Hannā wrote down his observations on daily life in the Ottoman capital as well as in the towns and villages on his way, commenting on the nature, food, and customs he encountered, narrating curious stories and anecdotes and occasionally mentioning political events. It is certainly not a coincidence that Hannā copied Arsāniyūs' account in the very year when he himself travelled to Istanbul, seven years after the end of Arsāniyūs' journey, and two years after he had become Bishop. He also concluded both accounts with the same verse by the seventh-century poet Qays b. Mulawwah. ${ }^{93}$ The colophon and the verse represent Hannā's particular signature. A common acquaintance of both brothers,

\footnotetext{
${ }^{91}$ For this observation, see Feras Krimsti, "The Lives and Afterlives of the Library of the Maronite Physician Ḥannā al-Ṭabīb (c. 1702-1775) from Aleppo,” Journal of Islamic Manuscripts 9 (2018): 206-207; $212-213$.

${ }^{92}$ Gotha, Ms. Orient. A 1550.

93 Gotha, Ms. Orient. A 1550, 147b (Hannā); Gotha, Ms. Orient. A 1549, 215a, and BO, USJ 1764, 194a (Arsāniyūs): قد يجمع الله الثتيتان [!] بعدما يظنان كل الظن ان لا تلاقيا
} 
Ḥannā Diyāb, also authored a travelogue. ${ }^{94} \mathrm{He}$ accompanied the French scholar, physician and antiquarian Paul Lucas (1664-1737) from 1707 to 1709 on a journey that led them through the Levant, Egypt, Libya and North Africa to Europe and France in particular. In Paris, he met Antoine Galland (1646-1715) and told him fourteen stories seven of which Galland added to the Arabian Nights. ${ }^{95}$ Interestingly, Hannā Diyāb wrote the account of his journey in 1763, aged 75, decades after the journey had taken place, and in the year before Hannā al-Ṭabīb set out to Istanbul. ${ }^{96}$ The flurry of authoring and copying activities relating to the three journeys about the same time is certainly significant. ${ }^{97}$

In the milieu of these travelers and authors, a number of very well-known contemporary travelogues were also circulating. The Sefaretname authored by the Ottoman diplomat Yirmisekiz Mehmed Çelebi Efendi (gest. 1732) was well-known in Aleppo. Yirmisekiz was

\footnotetext{
${ }^{94}$ Vatican, Sbath 254. For a French translation, see Hanna Dyâb, D'Alep à Paris: Les pérégrinations d'un jeune Syrien au temps de Louis XIV, transl. Paule Fahmé-Thiéry, Bernard Heyberger and Jérôme Lentin (Paris: Sindbad/Actes Sud, 2015).

${ }^{95}$ Ruth B. Bottigheimer, "East Meets West: Hannā Diyāb and the Thousand and One Nights," Marvels \& Tales: Journal of Fairy-Tale Studies 28/2 (2014): 304-306.
}

${ }^{96}$ Cf. Vatican, Sbath 254, 96a (trans. Hanna Dyâb, D'Alep à Paris, 263). The account was completed on 3 March 1764. Cf. Vatican, Sbath 254, 174a (trans. Hanna Dyâb, D’Alep à Paris, 440).

${ }^{97}$ Further travelogues, unrelated to those of the three travelers, who clearly knew each other and their travelogues, were produced in Aleppo. Ilyās al-Ghaḍbān, about whom virtually nothing is known, travelled from 13 April to 27 May 1755 to the Holy Land in the company of two priests. The first part of the travelogue comprises the dated itinerary, the second a description of the sanctuaries and the sites visited. See Ilyās al-Ghaḍbān, Al-Rihla almuqaddasa: Rihla qāma bihā Ilyās al-Ghaḍbān ilā ziyārat al-amākin al-muqaddasa fī Filisțīn fī 3 ibrül sanat 1755 m., ed. Ilyās al-Ghaḍbān (Cairo: Dār al-ma ārif, [c. 1948]). Yet another traveler, the Melkite Ibrāhīm al-Ḥakīm, left a travelogue of his journey to Egypt, when he fled Orthodox pressure in Aleppo around 1753. See Louis Cheikho, "Riḥlat Ibrahīm al-Ḥakīm al-Ḥalabī ilā Mișr," Al-Mashriq 10 (1907): 559-564; 581-586; 708-714. Cheikho's edition only contains a long excerpt from the travelogue. In contrast to the other travelogues mentioned above, Ibrahīm attempted to write classical Arabic and included poems and rhyme prose. 
sent to Paris on a diplomatic mission in 1720-1721. After his return, he wrote a report for Sultan Ahmed III (r. 1703-1730). The French ambassador, who received copies, made Julien-Claude Galland (a nephew of Antoine Galland) translate the text into French. ${ }^{98}$ Interestingly, at the exact time when Galland produced his translation, another French translation was prepared in Aleppo by a French dragoman named Joseph Aubert. ${ }^{99}$ Even more importantly, and surprisingly, Arabic translations of the Sefaretname were copied often in Aleppo. A number of such copies belonged to Christian families (though the exemplars were sometimes erroneously identified as the travelogue of Yirmisekiz' son, Mehmed Said Pasha). ${ }^{100}$ One Sefaretname translation was likely copied by Ḥannā Diyāb. ${ }^{101}$ Besides these travelogues, other earlier travel accounts clearly remained extremely popular in eighteenth century Syria. ${ }^{102}$

\footnotetext{
${ }^{98}$ Cf. Gilles Veinstein, "Introduction," in Mehmed efendi, Le Paradis des infidèles: Relation de Yirmisekiz Çelebi Mehmed efendi, ambassadeur ottoman en France sous la Régence, trans. J.-C. Galland (Paris: Maspero, 1981), $39-40$.

${ }^{99} \mathrm{Cf}$. Veinstein, "Introduction," 40.

${ }^{100}$ Gotha, Ms. Orient. A 1548 (owned by Hannā al-Ṭabīb), Vatican, Sbath 108 (owned by Hannā Diyāb) and St
} Petersburg, Ms. A. 255 (owned by Jurjī b. 'Abd Allāh Diyāb 1760 and by Yūsuf walad Ilyās Būlus Qara'lī 1777) ${ }^{101}$ Cf. for this suggestion John-Paul A. Ghobrial, "Stories Never Told: The First Arabic History of the New World," Osmanlı Araştırmalarl/ The Journal of Ottoman Studies 40 (2012): 263-264, especially n. 8. Hannā Diyāb may be mentioned in the manuscript as the first owner; unfortunately, the name is inked out. Antoine Rabbath was able to decipher it as "Hannā b. Diyāb al-Mārūnī fī Halab." Cf. Antoine Rabbath, Riḥlat awwal sharqī ilā Amrika wa-hiya siyāhat al-khūrī Ilyās b. al-Qassīs Hannā al-Mawșilī min 'aylat bayt 'Ammūn al-Kildān̄̄ 1668-1683 (Beirut: Al-Maṭba 'a al-kāthūlīkiyya, 1906), [2] (pagination not in edition).

102 Notably the aforementioned Rihlat al-Batriyark Makāriȳ̄s al-Halabī, authored by Būlus al-Za'īm, still garnered significant interest and was repeatedly copied. One copy in the Greek Orthodox Patriarchate in Damascus was completed on 19 May 1765. See Greek Orthodox Patriarchate in Damascus, Ms. 382, according to Ilyās Jubāra, Al-Makhțūtāat al- 'arabiyya fì maktabat Bațriyarkiyyat Anțākiya wa-sā' ir al-mashriq li-l-rūm al-urthūdhuks (Beirut: Markaz al-dirāsāt al-urthūdhuksī al-anțākī, 1988), 61. A second copy preserved in the Patriarchate has been dated to the eighteenth century. See Greek Orthodox Patriarchate in Damascus, Ms. 427, according to Jubāra, 
The interest travelogues encountered in eighteenth-century Aleppo and the Levant and the philological practices to which they gave rise should not be seen in isolation. Travelogues flourished in the Ottoman Empire at large during this period, particularly Ottoman travel accounts to Europe. ${ }^{103}$ From the beginning of the eighteenth century on, the number of travel accounts started to "increase markedly". ${ }^{104}$ This period was characterized by a veritable “institutionalization" of travel accounts. They acquired a social function as a genre. ${ }^{105} \mathrm{~A}$ veritable "institutionalization" of the genre also occurred in Aleppo. Ulrich Jasper Seetzen's articles about Arabic travelogues and geographical literature, which were published in Monatliche Correspondenz zur Beförderung der Erd- und Himmels-Kunde in 1805 and 1806, confirm this. He lists travelogues which he purchased or which were well-known towards the end of the eighteenth century. Besides Arsāniyūs and Ḥannā al-Ṭabīb, he lists, among others,

Al-Makhțịtāt al- 'arabiyya, 66. A copy of the manuscript preserved in the British Library has a colophon that again mentions 19 May 1765 as the date of completion. See British Library, Add Ms. 18430 (last volume), 103b. It is not clear if the copyist was a native of Aleppo. The name of the owner of the manuscript which is indicated in the first volume of the manuscript, 'Abd al-Masīh b. Mikhāyīl Anțākī, might point to a provenience either from Aleppo, or alternatively from Damascus. See British Library, Add Ms. 18427 (first volume), 2 a.

Besides Makāriyūs' text, Ilyās al-Mawșilī’s account of his journey to Central and South America also seems to have been known among Aleppo’s Christians. Vatican, Sbath Ms. 108 (owned by Ḥannā Diyāb). Cf. Ghobrial, “Stories Never Told,” especially 263-264 and 269.

${ }^{103}$ See Caspar Hillebrand, “Ottoman Travel Accounts to Europe: An Overview of Their Historical Development and a Commented Researchers' List," in Venturing beyond Borders-Reflections on Genre, Function and Boundaries in Middle Eastern Travel Writing, ed. Bekim Agai, Olcay Akyıldız and Caspar Hillebrand (Würzburg: Ergon, 2013).

${ }^{104}$ Cf. Hillebrand, "Ottoman Travel Accounts," 56.

105 On this period, see in detail Hillebrand, "Ottoman Travel Accounts," 61-67. 
Ibn Baț̣uțạ, Mehmed Said Pasha, and Makāriyūs, thus providing further evidence for the diffusion of their travelogues in particular. ${ }^{106}$

The activities of the copyists of Arsāniyūs travel account must be understood against this background of the institutionalization of the genre. The copying activities expanded access to the account by increasing its availability. But more than just copying the travel journal, the copyists created the travelogue in the first place, by transforming an alms-collector's diary into a pleasant read that did not bore its readers with unnecessary details of monastic communities, church buildings, and rites.

From travelogue to assortment of curiosities for the purpose of identity formation: Arsāniyūs' account as part of the anthology Majmā̄ al-azhār

In the second half of the nineteenth century, Arsāniyūs' account was yet again transformed through a new set of philological practices, when excerpts of the text were integrated into an anthology by Na' ūm Mikhā'îl Șaqqāl entitled Majma' al-azhār min al-ḥadīqa al-mu'ṭār ("Collection of Flowers from the Fragrant Garden"). The only extant copy of this anthology, unfortunately incomplete, is today preserved in the National Library in Cairo. ${ }^{107}$ Another one in Beirut seems to be lost. ${ }^{108}$

If we are to believe Paul Sbath, the anthology was probably well known among Aleppo's Christians. At least, individual chapters were. In his Al-Fihris, Sbath records several exemplars of Șaqqāl's Tārīkh qawmat Halab 1850 fì 'ahd Muhammd Zarīf Bāshā ("The History of the 1850 Uprising in Aleppo in the Times of Mehmed Zarif Paşa”) and Qawmat al-Shām sanat

\footnotetext{
${ }^{106}$ Cf. Seetzen, “Nachrichten,” 103 (Ibn Bațțūta), 104 (Mehmed Said Pasha), 105-109 (Arsāniyūs), 109-120; id., "Nachricht von einigen arabischen Reiseberschreibungen und andern geographischen und topographischen Werken,” Monatliche Correspondenz zur Beförderung der Erd- und Himmels-Kunde 14 (1806): 33 (Makāriyūs). ${ }^{107}$ See Cairo, Tārīkh Taymūr 2041.

${ }^{108}$ BO, USJ 59. On this manuscript, see Cheikho, “Catalogue raisonné,” 248, no. 59.
} 
1860 ("The Uprising in Damascus in 1860"), which form an integral part of the anthology. These two accounts were owned by seven Christian families in Aleppo around the beginning of the twentieth century. ${ }^{109}$ Like most of the works listed in Al-Fihris, however, no trace of these seven manuscripts remains.

Virtually nothing is known about Na' ūm Mikhā'îl Șaqqāl. The well-known Melkite Catholic al-Șaqqāl family comes to mind. However, given the content of the anthology, as I shall explain below, it is much more probable that $\mathrm{Na}^{\text {" }}$ "um was a Maronite. This assumption is corroborated by Sbath, who clearly identifies him as a Maronite. ${ }^{110}$

The table of contents of the anthology illustrates the thematic diversity of the fifteen chapters of which the book is constituted. The first five chapters have survived: an account of the 1850 uprising in Aleppo (chapter 1) ${ }^{111}$ and of its aftermath (chapter 2) are followed by excerpts from Arsāniyūs' travelogue (chapter 3). The ensuing chapter is devoted to the 1860 massacre in Damascus (chapter 4), upon which follows an excerpt from Arsāniyūs' apology for the Maronite church (chapter 5). ${ }^{12}$ Chapters six to thirteen are lost. According to the table of contents, they originally contained anecdotes such as the story of the Bedouin and the grammarian (chapter 6), excerpts from a work on mystical divination (chapter 7), riddles in poetic form (chapters 8 and 9), a selection of amusing anecdotes (chapter 10), a Jacobite (ya qūbiyya) (liturgical?) calendar (chapter 11), a chapter entitled "Evidence from the book of the Jews for the coming of Christ" (chapter 12) and a treatise on the perfection of God (chapter 13). The anthology concludes with two more chapters which have been preserved: the first lists

\footnotetext{
${ }^{109}$ Cf. Sbath, Al-Fihris, 55.

${ }^{110}$ Cf. Sbath, Al-Fihris, 55.

${ }^{111}$ On this chapter of the anthology, see the remarks in Feras Krimsti, Die Unruhen von 1850 in Aleppo: Gewalt im urbanen Raum (Berlin: Klaus Schwarz, 2014), 44-45; 191.

${ }^{112}$ A complete version of Arsāniyūs' apology has been preserved at Khonchara (Bikfayyā), Shuwayrite Basilian Order, OBC 355, 22b-81b. It was digitized by HMML: https://w3id.org/vhmml/readingRoom/view/120916.
} 
the time that has elapsed between certain mythical and historical events, such as the creation of the world, the birth of Jesus, or the conquest of Constantinople, and "today" (i.e. 1863) (chapter 14). The final chapter records more events from Aleppo's history, most of them concerning the Maronite community in the 1870 s (chapter 15).

The excerpts from Arsāniyūs' account in the anthology are based on a manuscript that seems close to the copy Seetzen brought to Gotha. This suggests that even before Seetzen's stay in Aleppo, contrary to what he thought, another copy of the manuscript existed. This is obvious from the presentation of a procession in Angers. The anthology also contains the procession; however, parts of it are omitted in the manuscript preserved in Beirut and only exist in the Gotha manuscript. ${ }^{113}$

Already the title of the chapter reflects new ways of processing its contents and the knowledge it transmits, Min siyāhat al-muțā̄n Shukrī Hakīm al-muḥtaram ("[Excerpts] from the Honored Bishop Shukrī Hakīm's Travels"). ${ }^{114}$ That the change from rihla to siyạha is not trivial becomes clear if we adduce a passage from Būlus al-Za 'īm's account of the journey of his father Makāriyūs. As mentioned above, this account loomed large in the eighteenth century thought-world, in which the genre of the travelogue flourished. Interestingly, Būlus insists on the utilitarian nature of his father's travelling. The latter, according to Būlus, travelled "neither delighting in sights nor promenading himself, no, nor visiting, but instead he was compelled by the strong distress of the times". ${ }^{115}$ The word سياحة , in the context of Arsāniyūs' journey seems

\footnotetext{
${ }^{113}$ For the entire procession, see Gotha, Ms. Orient. A 1549, 111b-113b, BO, USJ 1764, 87b-89b, Cairo, Tārīkh Taymūr 2041, 130-137 (here and below following the pagination in the manuscript). The passage in the anthology which overlaps only with Gotha, Ms. Orient. A 1549, 113a-113b, but not with the Beirut copy, is Tārīkh Taymūr 2041, 136-137.

${ }^{114}$ Cairo, Tārīkh Taymūr 2041, 61-137.

115 Qusțanțīn al-Bāshā, ed., Nukhba min safrat al-Bațriyark Makāriyūs al-Halabī (Harīṣā: Maṭba at al-Qiddīs Būlus, 1912), 7.
} 
to point to an altogether different understanding of the function of his travels. Not one of the anthology's excerpts from Arsāniyūs' account contains references to the original mission of the alms collector. In fact, the travelogue is barely even a travelogue: the episodes are not connected through the traveler's itinerary, the disposition of the material follows the chronology of the journey only loosely. From a travelogue, Arsāniyūs' account is turned into an assortment of curiosities, a collection of "flowers" in which the reader may take delight. The excerpts presented cover the Church of St. Jacques and the Abbey of St. Corneille in Compiègne, the gardens and zoo of Versailles, the Palace of Versailles, a clock and artifacts at the Palace, the Versailles Cathedral, religious processions in Paris, royal jewels, gardens in Paris, a church bell, a theatre performance, the hospital and opera in Rouen, the gifts given to the French king by Mahmud I in 1742, the Gardens of the Palacio Real de Aranjuez, a procession in honor of Saint Louis Bertrand in Valencia, a relic, a clock in a Spanish church, a Spanish hospital, the Igreja de São Roque in Lisbon and the aforementioned procession in Angers. These episodes are only occasionally introduced with localizations of the nature "we entered" (خلنا) or "I went to" (ذهبت); or "the narrator said" (قال الراوى, قال المخبر).117 Alternatively, the reader is addressed with "you should know, o reader..." (اعلم ايها القارى). ${ }^{118}$ This presentation accords with a strong tendency to deemphasize the journey aspect of the account - both its original motives as well as the itinerary and circumstances of the journey itself.

As a collection of strewn "flowers", the chapter devoted to Arsāniyūs' account mirrors on a smaller scale the overall project of the anthology: both bring together whatever held the contemporary reader's interest. The work's purpose is actually made quite explicit in the short

\footnotetext{
${ }^{116}$ Cairo, Tārīkh Taymūr 2041, 69, 94.

${ }^{117}$ Cairo, Tārīkh Taymūr 2041, 61, 65; 69, 118, 122; 123, 126, 130.

${ }^{118}$ Cairo, Tārīkh Taymūr 2041, 96.
} 
introduction. Șaqqāl here insists, "I am a collector, not an author, someone who puts into order, not someone who composes, neither do I concoct, nor even distort." ${ }^{119}$ He reports that his collection is modelled on another collection he discovered in his father's library and upon which he based himself, given that it was such a "nice read" (لطيف المطالعة).

As the anthology illustrates, what Șaqqāl considered a "nice read" potentially covered the latest local, regional and communal politics; such a read promised literary entertainment, provided useful knowledge, but above all, it reflected communitarian identity formation. Arsāniyūs' account did not only offer diversion. Both as a bishop and as a writer, he was also one of the community's eminent personalities. It is certainly not a coincidence that two of his writings were integrated into the anthology. (Descendants from Arsāniyūs' family also continued to rank high in the church hierarchy in the nineteenth century. ${ }^{121}$ ) The travelogue was therefore certainly not only integrated in the anthology because it was an entertaining read, but also because of its importance for Maronite identity formation.

The question of identity formation runs like a red thread through the entire work. The anthology establishes who the Maronites of Aleppo actually were: as Christians, in relation to the city's Muslims, in relation to other Christian communities, in relation to foreign nations, and even in relation to the Ottoman authorities.

It is not a coincidence that the anthology opens with two chapters devoted to urban unrest - the uprising in Aleppo in 1850 and the massacre in Damascus in 1860. These events overshadowed local, regional, and international politics for years to come. The two accounts, characterized by a strongly sectarian rhetoric, depict the events in terms of an antagonism

\footnotetext{
${ }^{119}$ Cairo, Tārīkh Taymūr 2041, 3.

${ }^{120}$ Cairo, Tārīkh Taymūr 2041, 4.

${ }^{121}$ Among them were Būlus Ārūtīn, Bishop of the Maronites from 1829 to 1851 and the grandson of one of Arsāniyūs' cousins (cf. Ghānim, Barnāmaj, 204-208) and Būlus Ḥak̄m, Bishop from 1885 to 1888 and a grandson of Arsāniyūs’ brother Hannā (cf. Ghānim, Barnāmaj, 214-218).
} 
between Christians and Muslims. ${ }^{122}$ Other chapters - such as the apology of the Maronite church, which discusses the question if John Marun (Yūḥannā Mārūn) was a saint or not seemingly tackle contentious issues that caused strife among different Christian communities. Aleppo's Melkites questioned the sainthood of the founding father of the Maronite church John Marun (to be distinguished from the fifth-century ascetic Marun). ${ }^{123}$ The topic of this chapter is a pivotal element in the assertion of Maronite primacy over local Uniates - a primacy that was founded on a claim that the Maronites were the only community that had been steadfast in its Catholicism since its beginnings in the fourth century. In its own way, the anthology therefore seeks "to unify and homogenize the dispersed and diverse community of Maronites into a normative cultural framework of Maronitism". ${ }^{124}$ Finally, even the concluding chapter, which records events occurring in Aleppo's Maronite community, places the Maronites, this time in relation to the Ottomans; it records, for example, how individuals from the community were honored by the Ottomans.

The integration of Arsāniyūs' travel account into the anthology can be better understood against this Maronite identitarian background. Interestingly, the excerpts selected from

${ }^{122}$ For a short analysis of the sectarian language in the account of the 1850 uprising, see Krimsti, Die Unruhen, 191.

123 This question had become a controversial issue in 1715, when Aleppo's Melkites, supported by some missionaries, denied his sainthood. In 1750, the Uniate Melkite Patriarch Cyril Tanas (d. 1760) destroyed a portrait of John Marun. In reaction to the complaints of the Maronites, in 1753, Pope Benedict XIV confirmed only the sainthood of the fifth-century ascetic Marun. It is in the context of repeated Melkite attacks that Arsāniyūs, then Maronite bishop of Aleppo, mounted the pulpit for a Lenten sermon in which he lauded John Marun in 1765. The apology has to be seen against the background of these quarrels. Cf. in detail Matti Moosa, The Maronites in History (Syracuse: Syracuse University Press, 1986), 167-173.

${ }^{124}$ See notably the remarks on Maronite self-assertion in Akram Fouad Khater, Embracing the Divine: Passion and Politics in the Christian Middle East (Syracuse: Syracuse University Press, 2011). Quotation ibid., 127 (Khater thus comments on histories written by Maronite intellectuals). 
Arsāniyūs' travelogue for the anthology are marked by a striking absence of any reference to the hardships the traveler experienced both in France as well as in Spain while collecting alms. In Orléans and Paris, as has been shown above, Arsāniyūs reports in detail about the trials he had to face in order to be permitted to collect alms, ${ }^{125}$ but the anthology only presents selections pertaining to gardens and palaces visited or curiosities seen. In Valencia, Arsāniyūs had to hide from the governor and was able to collect only a very limited amount of money. ${ }^{126}$ Nothing of this transpires in the anthology; only the description of processions is kept. All excerpts covering experiences in the Catholic nations of Europe are laudatory in character. To some extent such a selection mirrors the emphasis put on the ties between the Maronites and Catholic Europe (notably France and Spain) in a new era of sectarianism - French "humanitarian" and military intervention in the aftermath of the 1860 massacre in Damascus lay just a few years in the past, but France had long been perceived as an eminent protector of the Maronites and after 1860 was even more. The editor of Arsāniyūs' travelogue, Ferdinand Taoutel, would later ironically reflect on the use the Maronites made of texts lauding France and the French in order to affirm and display their relation to the French. ${ }^{127}$ The travelogue written by Fransīs Marrāsh in 1867 on the occasion of his journey to Paris, ${ }^{128}$ roughly at the same time when the anthology was compiled, is similar in its enthusiastic appraisal of France and French "civilization" (تمدن), although different in its literary ambitions.

\section{Arsāniyūs' travelogue as a repository for factual history: the project of its edition}

\footnotetext{
${ }^{125}$ Gotha, Ms. Orient. A 1549, 128b-131a.

${ }^{126}$ Gotha, Ms. Orient. A 1549, 173a, 174a.

127 Taoutel, “Riḥlat al-ab Arsāniyūs,” 231.

${ }^{128}$ See Fransīs Fatḥallāh Marrāsh, Riḥlat Bārīs 1867, ed. Qāsim Wahb (Beirut: Mu'assasa al- 'arabiyya li-1-dirāsāt wa-1-nashr, 2004).
} 
Arsāniyūs' travelogue entered the next stage of philological engagement when it was edited by the Jesuit scholar Ferdinand Taoutel (1887-1977). Taoutel was born into a Maronite family in Aleppo in 1887. He joined the Jesuit order in 1906. With the exception of two years during which he lived in Cairo, he lived between Aleppo and Beirut, permanently residing in Beirut for the last thirty years of his life. ${ }^{129}$

Beginning in 1921, for over forty years, Taoutel published numerous studies and articles covering a wide spectrum of topics. Many of them appeared in the journal Al-Mashriq, founded in 1898 by Louis Cheikho. The journal was a "Jesuit directed enterprise" which "offered to the educated Arab the rediscovered literary treasures of his own heritage". ${ }^{130}$ Taoutel was one of the last from among a generation of Jesuits still born in Ottoman times whose scholarly work informed the journal. Cheikho and his colleagues, who were priests and scholars at the same time, through their editions determined which early modern manuscripts were to be brought to the awareness of their readers.

In the year in which the journal Al-Mashriq was launched, the Jesuit and Orientalist Henri Lammens (1862-1937) published a programmatic article that sheds light on the project of the journal's pioneers. This programmatic framework is decisive for understanding Taoutel's motives for editing Arsāniyūs' travelogue. Lammens" article is entitled "Let us study the history of our country: plan for the organization of societies devoted to the study of history." ${ }^{131}$ In this

\footnotetext{
${ }^{129}$ Cf. Kamīl Ḥushayma, Al-Mu'allifün al- 'arab al-masīhiyyūn min qabl al-islām ilā ākhir al-qarn al- ishrīn, vol. 2 (Beirut: Dār al-Mashriq, 2011), 278-279.

${ }^{130}$ On the journal Al-Mashriq under the editorship of Louis Cheikho, see Robert Bell Campbell, "The Arabic Journal, Al-Mashriq: Its Beginnings and First Twenty-Five Years under the Editorship of Père Louis Cheikho" (unpublished PhD diss, University of Michigan, 1972). Quotation ibid., 3.

${ }^{131}$ See Henri Lammens, "Hayyā 'alā dars tārīkh bilādinā: șūrat tanẓ̄m jam iyya li-dars al-tārīkh,” Al-Mashriq 1 (1898)
} 
article, Lammens calls for "a new approach to the study of history", ${ }^{132}$ founded on the Rankean vision of a study of the past "wie es eigentlich gewesen". Besides arguing for the foundation of communal societies devoted to the study of history and discussing their financing, he puts forward a program in ten points. The second of these points is of particular relevance for the present argument. Lammens demands that the historical societies "take sections and passages which are related to the history of the community from the historians, travelogue writers ( رواة and the other authors, and publish them in their original language (لغتها الاصلية)".133 The publication of Arsāniyūs' travelogue has to be seen as part of the project to provide “contemporary evidence" (الإلة الراهنة), 134 which, Lammens contends, is the necessary foundation for the historical approach for which Al-Mashriq stands. There is no doubt that Taoutel knew Lammens' programmatic article, given that he refers to it in a footnote of his edition of Isțifānūs al-Duwayhī’s work "History of the Ages" (Tārīkh al-azmina). ${ }^{135}$ In 1924, Taoutel and Lammens also published together a book in French and Arabic entitled Mukhtașar tārīkh Sūriya wa-Lubnān ("Short History of Syria and Lebanon”). ${ }^{136}$

A byproduct of Taoutel's work for Al-Mashriq was a series of books comprising material published in the journal since 1937 under the title Wathà iq tārìkhiyya 'an Halab ("Historical Documents from Aleppo"). Taoutel was in Aleppo at this time (1937-1947) and had the occasion to conduct research in church archives and private collections. A first result of these activities was the publication of the diary written by the Syrian Catholic teacher Na ' $\mathrm{um}$

\footnotetext{
${ }^{132}$ Lammens, “Hayyā,” 261.

${ }^{133}$ Lammens, "Hayyā," 262.

${ }^{134}$ Lammens, “Hayyā,” 261.

${ }^{135}$ Ferdinand Taoutel, ed., “Al-Bațrīyark Isțifānūs al-Duwayhī: Tārīkh al-azmina 1095-1699,” Al-Mashriq 44 (1950): 16.

${ }^{136}$ Cf. Hushayma, Al-Mu'allifün, 279. The work was not available to me.
} 
Bakhkhāsh (d. after 1875) in the Aleppo dialect. ${ }^{137}$ The edition of the diary sheds light on Taoutel's philological and historical ambitions. Taoutel reports having encountered the egodocument for the first time in school, when a teacher read from the diary. Upon discovering the four volumes in the house of a Christian family in Aleppo, he decided to publish them. In a paragraph of the introduction to this work entitled "Bakhkhāsh's language: the literary value of the book", ${ }^{138}$ he poses the question if the use of colloquial language and what were perceived as linguistic "mistakes" should be seen as an argument against the publication of the work, answering this question himself negatively:

This is so because correct scientific publication has to go back to the original version, as it was penned by the author [...]. The scholars of the cultural renaissance started to concern themselves with the study of the regional dialects, because from their particular features of expression and grammatical construction and from comparison between them, the essential traits of the classical Arabic language and its development emerged. This approach became a part of Arabic philology and the history of language, as Orientalists called for paying attention to [language] and for recording it for every country or Arabic-speaking region. [...] It is just short-sighted and a sign of ignorance to disdain $\mathrm{Na}$ 'ūm Bakhkhāsh's language since it contains vestiges resembling those coins that they find during excavations, displaying images of kings and names of gods that were well-known in our country in the days when they were used. It is the state of

\footnotetext{
${ }^{137}$ See Ferdinand Taoutel, ed., Wathā’iq tārīkhiyya 'an Halab, vol. 1, Al-Hawādith wa-l-akhbār akhdhan 'an yawmiyyat Na"ūm al-Bakhkhāsh (1855-1865) wa-ghayruhā min al-makhțūtāat (Beirut: Al-Maṭba'a alkāthūlīkiyya, 1940).

${ }^{138}$ Taoutel, Wathä 'iq, 1:8-11.
} 
the language of past times, an interpreter of circumstances then, an authority for its history. ${ }^{139}$

This view is paradigmatic for Taoutel's engagement with the language of the material he edited. He passionately defended non-standard varieties of Arabic. For Taoutel, ego-documents such as the diary, but also all other historical texts, were repositories of factual information about the past, both on the level of content as well as on the level of the language the integrity of which he preserved.

A schism between past and present emerges from Taoutel's comments: a schism that tallies with the binaries instituted by the Nahḍa, which continued to be propagated (premodern vs. modern, civilized vs. uncivilized). The Nahḍa functioned, as Nadia Bou Ali has claimed, "as an archive for the "Arab nation' and thereby 'Arab history"” by consigning together "the corpus of Arab History in modern time". ${ }^{140}$ Taoutel shares this specific vision of the past in relation to the present. In particular, his idea of language containing "vestiges" of the past resonates with views articulated, for example, by the American missionary Eli Smith, who claimed that the Arabic language, like its ruins, "told the secrets of history". ${ }^{141}$

\footnotetext{
139 Taoutel, Wathä 'iq, 1:8-9.

"وذلك لان النشر العلمي الصحيح يلزم الناشر رواية الاصل كما خرج من قلم محرره ما لم يكن مانع معقولـونه، وان اصحاب النهضة الثقافية

الحاضرة صاروا يهتمون بدرس اللغات المكانية، لان من ميزاتها في اللفظ و التركيب ومن المقابلة بينها تتكون ميزات اللغة العربية الفصحى في تطور ها. فصارت هذه الناحية من نواحي العلوم العربية \زءًا من فقه اللغة وتاريخها، مما عا بالمستشرقين الى العناية بها وتدوينها لكل بلدة او اقليم من الاقاليم الناطقة بالضبا. [...] فقد يكون من نتيجة قصر النظر والجهل احتقار لغة نعوم البخاش وفيها آثار اشبه بتلك النقوم التي يكتشفونها في الحفريات و عليها صور الملوك و اسماء الآلهة التي شاع ذكر هم في بلإنا ايام استعمال تللك النقوَ، فهي لسان حال الزمان الماضي، وترهمان احواله،

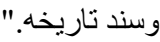

${ }^{140}$ Nadia Bou Ali, "Collecting the Nation: Lexicography and National Pedagogy in al-nahda al-'arabiyya," in Archives, Museums and Collecting Practices in the Modern Arab World, ed. Sonja Mejcher-Atassi and John Pedro Schwartz (Farnham/ Burlington: Ashgate), 33-56.

${ }^{141}$ Quoted by Bou Ali, “Collecting the Nation,” 35.
} 
The partial edition of Arsāniyūs' account appeared relatively late in Taoutel's life, between April 1967 and February 1968, in four parts in Al-Mashriq. The last part closes like the other parts with the note "to be continued". ${ }^{142}$ The next part of the travelogue, however, never appeared. This might have been due to health reasons. Taoutel died, after a long illness, in 1977 and with few exceptions, there were scarcely any publications in the decade before his death. It is also possible that the discontinuation of the edition was brought about by the end of the publication of the journal Al-Mashriq, the last issue of which appeared in 1970. The publication was only resumed in 1991, when the Lebanese Civil War had ended.

Tatoutel's edition of the travelogue is based on the Manash-Mukarbana manuscript, which he presented faithfully and with few divergences. In accordance with his views on the preservation of the "original" language of a given historical text, he made very few linguistic changes, adjusting the language in order to delete perceived "mistakes pertaining to inflection and grammar" (الاغلاط الصرفية والنحوية), without changing the meaning (معانيه). ${ }^{143}$ For example, plural endings were changed from $-\bar{l} n$ to $-\bar{u} n,{ }^{144}$ the female word ending $h \bar{a}^{\prime}$ replaced with $t \bar{a}^{\prime}$ marbūta ${ }^{145}$ or accusative case endings corrected. ${ }^{146}$

Taoutel obviously intended to offer his readers an unaltered version of Arsāniyūs' travelogue, the editorial project receding unobtrusively into the background. The text was not charged with political meaning or used as an ideological instrument, nor was it inserted into debates about modernization, nationalism, nor debates about the Arabic language. In Taoutel's rendering of the travelogue, the narrative primarily serves as a window unto the past; it is judged solely with regard to its "veracity" (صدق). Taoutel addresses this concept explicitly: in his

\footnotetext{
142 Taoutel, “Riḥlat al-ab Arsāniyūs," 120.

143 Taoutel, “Riḥlat al-ab Arsāniyūs,” 227.

${ }^{144}$ See for example 'ishrīn vs. 'ishrūn in BO, USJ 1764, 21 b vs. Taoutel, "Riḥlat al-ab Arsāniyūs,” 256.

${ }^{145}$ See for example kan̄̄sah vs. kanīsa in BO, USJ 1764, 21 b vs. Taoutel, “Rihlat al-ab Arsāniyūs,” 255.

${ }^{146}$ See for example dirā' vs. dhirā'an in BO, USJ 1764, 24b vs. Taoutel, "Rihlat al-ab Arsāniyūs," 260.
} 
introduction, he devotes a paragraph to "Arsāniyūs' veracity in narration and description". ${ }^{147}$ In this paragraph, he adduces the example of the "Arabian Princes" in order to demonstrate the truthfulness of Arsāniyūs' account, checking it against Carsten Niebuhr's comments. ${ }^{148}$ The concept of veracity resurfaces elsewhere in a footnote relating to Arsāniyūs' description of a puppet play, which Taoutel corroborates with experiences he himself made while watching a performance by Italian marionette players in 1965 in Beirut. ${ }^{149}$ The text and the veracity of the knowledge it articulates being so strongly foregrounded, Arsāniyūs, as the author of the travelogue, appears bereft of any agency. Neither his project to collect alms nor his literary activities are considered in the introduction or the footnotes. A symptom of this precarious existence of the author in Taoutel's edition is the fact that Taoutel confounds Arsāniyūs Shukrī and Arsāniyūs 'Abd al-Ahad, ${ }^{150}$ or compares him elsewhere to the Russian mystic Rasputin (1869-1916), due to his close relation with the Queen of France, Marie Leszczyńska (17031768), which resembled the relation between the mystic and Alexandra Feodorovna, the Empress of Russia (1872-1918). ${ }^{151}$

Arsāniyūs' account of his journey to Catholic Europe was among the last Christian travelogues from Ottoman times to be edited and published by a generation of scholars who were active during the so-called nahḍ. It was preceded by a number of related projects, for example, by Antoine Rabbath’s (1867-1913) edition of Ilyās al-Mawṣilī’s travelogue, which appeared in $1906 .{ }^{152}$ This edition is based on a manuscript that is now known as Vatican, Sbath 108. In the introduction to the edition, Rabbath comments that "the literary style [of the

\footnotetext{
147 Taoutel, “Riḥlat al-ab Arsāniȳuss," 229.

${ }^{148}$ Cf. Taoutel, “Riḥlat al-ab Arsāniyūs,” 229-230.

${ }^{149}$ Cf. Taoutel, “Riḥlat al-ab Arsāniyūs,” 547-548, n. 2.

${ }^{150}$ Cf. Taoutel, “Riḥlat al-ab Arsāniyūs,” 228.

${ }^{151}$ Cf. Taoutel, “Riḥlat al-ab Arsāniyūs,” 231.

${ }^{152}$ See Rabbath, Riḥlat awwal sharqī.
} 
travelogue] is weak (نفاءه ركيك) and its descriptions are lacking in skill (تفنـ)." Despite these shortcomings, the "curious things" (الامور الغريبة) described in the text caught his interest. When editing the text, Rabbath only improved what he perceived as "major grammatical mistakes", leaving awkward-sounding constructions as they were. His approach to the make-up of the text thus anticipated Taoutel's. Rabbath further expressed the hope that his edition would benefit Syrians living in the countries the traveler visited, by showing the wild past of these countries, which were now civilized thanks to missionary activities. ${ }^{153}$ The text was obviously conceptualized as a repository for factual information about the history of South America that could be potentially beneficial for Rabbath's contemporaries, rather than the self-expression of the traveler Ilyās. This anticipates Taoutel's approach to Arsāniyūs' text. Interestingly, Rabbath abstained from editing an extensive part of the account that covers the history of South America, declaring that he did not find it useful (most probably because it was a translation of historical texts and as such not "original").

Louis Cheikho's (1859-1927) 1914 edition of Yirmisekiz' account of his journey to Paris, is in continuity with Rabbath's project and similarly anticipates Taoutel's. ${ }^{154}$ It is based on the other half of manuscript Sbath 108, with which Rabbath had not dealt. Cheikho's introduction to his edition of the Ottoman diplomat's travelogue is rather short and provides the reader with the historical background to the mission. He observes that the text was translated into Arabic. By whom he does not know but he surmises that it might have been someone from على ( Aleppo on account of the dialect. He then adds, "we left the translation as it originally was (اصلها), despite the weak language of the Arabic version (مع ركاكة تعريبها)."155 Again, extensive

\footnotetext{
${ }^{153}$ Cf. Rabbath, Rihlat awwal sharqī, [2] (no pagination in edition). All quotations ibid.

${ }^{154}$ See Louis Cheikho, "Riḥlat Muḥammad Sa īd Bāshā ilā Bārīs,” Al-Mashriq 17 (1914): 101-116; 176-192; 251262.

${ }^{155}$ Cf. Cheikho, "Riḥlat Muḥammad Sa īid Bāshā," 103.
} 
interventions altering the linguistic fabric are avoided. And again, the primary concern motivating the editorial project is historical. This emerges from the disposition of the text: it is interspersed with images, maps and excerpts from documentary sources which attest to the veracity of the travelogue's contents. ${ }^{156}$ For example, Cheikho inserts an excerpt from the memoires of the Duc du Saint Simon in French, which mention Yirmisekiz' arrival in Paris. ${ }^{157}$ Yet another travelogue is approached as a repository for historical facts with a claim to absolute veracity.

A number of other editorial projects of travelogues could be mentioned to elucidate Taoutel's approach. A glimpse at Qusțanțīn al-Bāshā's edition of excerpts of Makāriyūs' journey, which was published in 1912, can suffice here. ${ }^{158}$ In the introduction to al-Bāshā's edition, an approach that has by now become familiar is outlined: "we left the book as it originally was (على اصله)", al-Bāshā states, "neither suppressing nor altering anything, despite the grammatical mistakes (اللحن) it contains". He argues that he proceeded in this way to safeguard the "historical vestiges" (الاثار التاريخية).

The aforementioned examples point to a surge in editorial activities relating to travelogues in the Levant in the early and mid-twentieth century. Travelogues (and egodocuments more generally) were appreciated as sources for a history "wie es eigentlich gewesen", as instruments for creating, controlling and safeguarding historical heritage. Interestingly, this ties in with observations that scholars have made on editions of other egodocuments. Dana Sajdi has examined the edition of the chronicle composed by Shihāb al-Dīn

\footnotetext{
${ }^{156}$ For images and maps cf. Cheikho, "Riḥlat Muḥammad Sa '̄id Bāshā,” 104-105.

${ }^{157}$ Cf. Cheikho, "Riḥlat Muḥammad Sa '̄id Bāshā,” 189-192.

${ }^{158}$ See al-Bāshā, Nukhba.

${ }^{159}$ Al-Bāshā, Nukhba, 5.
} 
Ahmad b. Budayr (fl. 1762), the so-called "Barber of Damascus". ${ }^{160}$ She notes that the interventions by the editor of the chronicle, Muhammad Sa'̄id al-Qāsimī (d. 1900), "betray something larger: namely the transformation of history from reports on current events into a document about heritage or a collection of legacies". ${ }^{161}$ In contrast to the editorial projects discussed above, al-Qāsimī edited the chronicle with a heavy hand, effectively ridding it of the barber-author by resorting to extensive omissions and manipulations of the text. ${ }^{162} \mathrm{He}$ also ventured to "improve" its language substantially. ${ }^{163}$ While Taoutel and the other editors commented on what they perceived as linguistic "weaknesses" of the texts they worked with, they abstained from major interventions. And yet: by divesting the author of his prominence and treating the text itself as a site for the excavation of the historical heritage, Arsāniyūs' travelogue received a treatment not very different from the one meted out to the barber's chronicle in the process of its edition.

\section{Conclusion}

In 1990, when the journal Speculum published its special issue on The New Philology, the editor of the volume, Stephen G. Nichols, criticized a previous generation of scholars dealing with philology for their reliance on edited texts:

\footnotetext{
${ }^{160}$ For a study of the chronicle, see Dana Sajdi, The Barber of Damascus: Nouveau Literacy in the EighteenthCentury Ottoman Levant (Stanford: Stanford University Press, 2013). The edition is discussed at length in chapter 6 "Cutting the Barber's Tale," 174-204.

${ }^{161}$ Sajdi, The Barber, 175.

${ }^{162}$ Cf. Sajdi, The Barber, 198-204. The section of the chapter is entitled "Muting the Barber's Voice."

${ }^{163}$ Cf. Sajdi, The Barber, 187-93.
} 
By its origins, in Auerbach's view, philology represented a technological scholarship made possible by a print culture. It joined forces with the mechanical press in a movement away from the multiplicity and variance of manuscript culture, thereby rejecting, at the same time, the representation of the past which went along with medieval manuscript culture: adaptation or translatio, the continual rewriting of past works in a variety of versions [...]. In its place, the philology inherited by Auerbach's generation installed a preoccupation with scholarly exactitude based on edited and printed texts. The high calling of philology sought a fixed text as transparent as possible, one that would provide the vehicle for scholarly endeavor but, once the work of editing was accomplished, not the focus of inquiry. It required, in short, a printed text. ${ }^{164}$

Nichols emphasized, following Bernard Cerquiglini, that "medieval writing does not produce variants; it is variance". While his call was subsequently read as an equation of philology with textual editing, he is in effect concerned with the "medieval origins of philology". ${ }^{165}$ It was in the variance of manuscript culture that he detected the ongoing philological work of the past. These philological activities resulted in a continual processing and rewriting of the past.

The present article has also uncovered a space for premodern philological engagement in variance between manuscripts. Studying the variance between different manuscript versions of Arsāniyūs' account of his journey to France, the Iberian Peninsula, and Italy, and one printed version, sheds light on what philology in Arabic in the premodern world meant, at different times, in different epistemic and social contexts.

Arsāniyūs' text did not come into existence as a travelogue all at once; it was first an alms-collector's journal, written to document the traveler's itinerary and record experiences

\footnotetext{
${ }^{164}$ Stephen G. Nichols, “Introduction: Philology in a Manuscript Culture," Speculum 65.1 (1990): 2-3.

${ }^{165}$ Nichols, "Introduction," 1 (both quotations).
} 
that he considered potentially useful for others, with an accent on ecclesiastical infrastructure. It was a booklet written for the very practical purpose of self-authentication and documentation in the 1740s and 50s, before it was copied and modified so as to match the expectations of a readership that had become enchanted with the travelogue genre in the second half of the eighteenth century. The process of copying and thus diffusing the account, but also interventions by copyists such as stylistic modifications and abridgments, resulted in a text which satisfied the expectations of a readership not particularly interested in the knowledge of the alms-collector but eager to learn about knowledge of the world imparted together with it. When the travel account was integrated in the second half of the nineteenth century into an anthology by Na' 'ūm Mikhā'îl Șaqqāl, the travel component itself receded completely into the background; an assortment of "curiosities" only loosely related to one of the Maronite communities' eminent figures remained. No longer a process of abridgment, but one of selection, had produced a text that was part and parcel of a broader project of Maronite identity formation. Finally, Ferdinand Taoutel strove to fix the text in the framework of his editorial project, turning the articulations of a global actor into local heritage. The travel account came to be understood as an archive for Arab history, in harmony with ideas constituting what is commonly designated as the Nahḍa.

Which of these different versions of the text, one might ask, is "Arsāniyūs' travel account"? It would certainly be wrong to single out any particular stage in the history of the text. In a way, they all make up the account, and both the historian and philologist have to consider carefully which stage of the textual genesis to consider in order to find answers to their questions, instead of automatically privileging what Nichols has insightfully called "a fixed text as transparent as possible”.

Paradoxically, Taoutel's edition of Arsāniyūs' travelogue, which was supposed to serve the publication and circulation of the text to promote its study, heralded a temporary pause in the work on the text; like many early modern texts, the travelogue was virtually forgotten. 
Nevertheless, it would be wrong to speak of the end of the philological engagement with the text tout court. The study of the text among priests continued into the second half of the twentieth and into the twenty-first centuries. On 8 August 1971, the Maronite priest Luwīs b. Fīlīb Ni 'matallāh Șaqqāl studied the copy of Arsāniyūs' travelogue in Beirut, leaving a marginal note announcing that he added toponyms in Latin script on the margins of the manuscript, in order to clarify the Arabic transcriptions of names of cities and towns. ${ }^{166}$ And indeed, written in the same blue ink, Șaqqāl's annotations can be traced throughout the manuscript. Although marginal notes penned by modern readers in manuscripts are now generally considered a librarian's nightmare, Luwīs Ṣaqqāl certainly attempted nothing more than to make the text again more transparent and accessible. Hands-on work of this nature by individuals certainly remained the exception in the second half of the twentieth century. However, the digital age can be expected to usher a new phase of philological engagement with the text. The digitization of the Beirut copy of Arsāniyūs' travelogue along with great numbers of other manuscripts was a first significant step in this direction. The new accessibility of manuscripts online might provide an important stimulus for the resumption of philological work on the text. The present study itself is a case in point.

\section{Bibliography}

\section{Manuscripts}

\section{Aleppo, Maronite Diocese:}

Ms. 1354 (anonymous, but attributed to Arsāniyūs Shukrī, Tārīkh ruhban al-lubnāniyyīn mundhu ibtidā rahbanatihim fĩ jabal Lubnān al-mubārak)

${ }^{166}$ BO, USJ 1764, $199 b$. 


\section{Beirut, American University:}

Ms. 735, Ms. 976 (Fīlibūs Numayr, Irtihālat al-khūrī Mūsā Muqaḥhaṭ wa-l-khūrī Fūlibūs Numayr ilā al-Urūbā)

\section{Beirut, Bibliothèque Orientale:}

BO, USJ 59 (Na 'ūm Mikhā’̄̄l Șaqqāl, Majma' al-azhār min al-ḥadīqa al-mu'ṭār) must be regarded as lost

BO, USJ 1764 (Arsāniyūs Shukrī, Riḥlat al-ab Arsāniyūs Shukrī al-rāhib al-Halabī l-Lubnānī; HMML, reading room: https://www.vhmml.org/readingRoom/view/129738)

\section{Cairo, National Library:}

Tārīkh Taymūr 2041 (Na 'ūm Mikhā’îl Șaqqāl, Majma 'al-azhār min al-ḥadīqa al-mu 'tār)

\section{Chur, Cantonal Archives of Graubünden:}

Ms. B-14 (anonymous, untitled travel journal and cashbook)

\section{Gotha, Research Library:}

Ms. Orient. A 146 (Collection of lose manuscript pages)

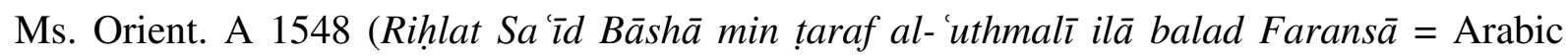
translation of Yirmisekiz Çelebi Mehmed Efendi’s Sefaretname)

Ms. Orient. A 1549 (Arsāniyūs Shukrī, Riḥlat al-ab Arsāniyūs Shukrī al-rāhib al-Halabī l-

\section{Lubnānī)}

Ms. Orient. A 1550 (Ḥannā al-Ṭabīb, Riḥlat al-Shammās Hannā al-Ṭabīb ilā baldat Istanbūl)

\section{Khonchara (Bikfayyā), Shuwayrite Basilian Order:}

OBC 355 (Untitled polemics against the Maronites and response by Arsāniyūs Shukrī; HMML, reading room: https://w3id.org/vhmml/readingRoom/view/120916)

\section{London, British Library:}

Add Ms. 18427-18430 (catalogued as “Travels of Macarius, Patirarch of Antioch, in Turkey and Russia, 1652-1659; by his son, Archdeacon Paul of Aleppo")

\section{St Petersburg, National Library of Russia:}


Ms. A. 255 (Rihlat Sa ìd Bāshā min țaraf al- 'uthmalī ilā balad Faransā = Arabic translation of Yirmisekiz Çelebi Mehmed Efendi’s Sefaretname)

\section{Vatican, Bibliotheca Apostolica Vaticana:}

Sbath 108 (Ilyās al-Mawșilī, Kitāb siyāḥat khūrī Ilyās al-Mawṣilī; untitled Arabic translation of the Sefaretname; DigiVatLib: https://digi.vatlib.it/view/MSS_Sbath.108)

Sbath 254 (Hannā Diyāb, untitled travelogue; beginning of the manuscript missing; DigiVatLib: https://digi.vatlib.it/view/MSS_Sbath.254)

\section{Books, articles, and other printed texts}

Abras, Michel. "Le Voyage de deux moines melkites en Italie du Nord en 1775." In Les Européens vus par les Libanais à l'époque ottomane, edited by Bernard Heyberger and Carsten-Michael Walbiner, 59-65. Beirut: Ergon, 2002.

Al-Bāshā, Qusțanțīn, ed. Nukhba min safrat al-Bațiyark Makāriyūs al-Halabī, Ḥarịṣā: Maṭba at al-Qiddīs Būlus, 1912.

Bill, Claus Heinrich. “'Olivenprinzen' im Deutschland der Frühen Neuzeit: Zwischen Morgenlandfaszination und religiöser Solidarität. Zum Finanzierungstourismus maronitischer mittelneuzeitlicher männlicher Libanesen 1750-1800.” Nobilitas: Zeitschrift für deutsche Adelsforschung 24 (2002): 1184-1210.

Blair, Ann M. Too Much to Know: Managing Scholarly Information before the Modern Age. New Haven: Yale University Press, 2010.

Bottigheimer, Ruth B. "East Meets West: Hannā Diyāb and the Thousand and One Nights." Marvels \& Tales: Journal of Fairy-Tale Studies 28/2 (2014): 302-324.

Bou Ali, Nadia. "Collecting the Nation: Lexicography and National Pedagogy in al-nahda al'arabiyya." In Archives, Museums and Collecting Practices in the Modern Arab World, edited by Sonja Mejcher-Atassi and John Pedro Schwartz, 33-56. Farnham/ Burlington: Ashgate, 2012. 
Bulaybil, Lūwis. Tārīkh al-Rahbāniyya al-lubnāniyya al-mārūniyya, vol. 2. Cairo: Maṭba'at Yūsuf Kawā, 1925.

Campbell, Robert Bell. “The Arabic Journal, Al-Mashriq: Its Beginnings and First Twenty-Five Years under the Editorship of Père Louis Cheikho.” Unpublished PhD diss, University of Michigan, 1972.

Cheikho, Louis [Luwīs Shaykhū]. "Riḥlat Ibrahīm al-Ḥakīm al-Ḥalabī ilā Miṣr.” Al-Mashriq 10 (1907): 559-564; 581-586; 708-714.

—. "Catalogue raisonné des manuscrits historiques de la Bibliothèque Orientale de 1’Université St Joseph.” Mélanges de la Faculté Orientale 6 (1913): 213-304 (reprint from 1973).

—_. "Riḥlat Muḥammad Sa īd Bāshā ilā Bārīs.” Al-Mashriq 17 (1914): 101-116; 176-192; 251-262.

—. Kitāa al-Makhțūtât al- 'arabiyya li-katabat al-nașrāniyya. Beirut: Imprimerie Catholique, 2000 (reprint of the 1924 edition).

Dayeh, Islam. “The Potential of World Philology.” Philological Encounters 1 (2016): 396-418.

Dyâb, Hanna. D'Alep à Paris: Les pérégrinations d'un jeune Syrien au temps de Louis XIV. Translated by Paule Fahmé-Thiéry, Bernard Heyberger and Jérôme Lentin. Paris: Sindbad/Actes Sud, 2015.

Elger, Ralf. "Die Reisen eines Reiseberichts_-Ibn Baț̣ūṭas Riḥla im Vorderen Orient des 17. und 18. Jahrhunderts." In Buchkultur im Nahen Osten des 17. und 18. Jahrhunderts, edited by Tobias Heinzelmann and Henning Sievert, 53-98. Bern: Peter Lang, 2010.

—. "Introduction." In Many Ways of Speaking about the Self: Middle Eastern Ego-Documents in Arabic, Persian, and Turkish $\left(14^{\text {th }}-20^{\text {th }}\right.$ century), edited by Ralf Elger and Yavuz Köse, 7-14. Wiesbaden: Harrassowitz, 2010.

—. Glaube, Skepsis, Poesie: Arabische Istanbul-Reisende im 16. und 17. Jahrhundert. Beirut: Orient-Institut, 2011. 
Fahd, Buțus. Tārīkh al-rahbāniyya al-lubnāniyya al-mārūniyya, vol. 4. Jounieh: Mațābi` alkarīm al-ḥadītha, 1966.

—. Tārīkh al-rahbāniyya al-lubnāniyya al-mārūniyya, vol. 5. Jounieh: Mațābi` al-karīm alhadītha, 1967.

—. Baṭārikat al-mawārina wa-asāqifatuhum: Al-qarn 18. Beirut: Dār Laḥd Khāṭir, 1985.

al-Ghaḍbān, Ilyās. Al-Riḥla al-muqaddasa: Rihla qāma bihā Ilyās al-Ghaḍbān ilā ziyārat alamākin al-muqaddasa fì Filisțīn fì 3 ibrīl sanat 1755 m., edited by Ilyās al-Ghaḍbān, Cairo: Dār al-ma'ārif, [c. 1948].

Ghānim, Yūsuf Khaț̣āar. Barnāmaj akhawiyyat al-qiddīs Mārūn, vol. 2. Beirut: Al-Maṭba‘ alkāthūlīkyya, 1903.

Ghobrial, John-Paul A. "Stories Never Told: The First Arabic History of the New World." Osmanlı Araştırmalarl/ The Journal of Ottoman Studies 40 (2012): 259-282.

—. "The Secret Life of Elias of Babylon and the Uses of Global Microhistory." Past \& Present 222.1 (2014): 51-93.

—. "Migration from Within and Without: In the Footsteps of Eastern Christians in the Early Modern World.” Transactions of the Royal Historical Society 27 (2017): 153-173.

Graf, Georg. Geschichte der christlichen arabischen Literatur, vol. 3, Die Schriftsteller von der Mitte des 15. bis zum Ende des 19. Jahrhunderts: Melchiten, Maroniten. Vatican, Biblioteca Apostolica Vaticana, 1949.

Graf, Tobias P. ““Arabian Princes’: Performance and the Imagined Eastern Mediterranean in the Eighteenth-Century Holy Roman Empire.” (In preparation.)

Heyberger, Bernard. "Chrétiens orientaux dans 1'Europe catholique (XVII $-X V I I I^{\mathrm{e}}$ siècles)." In Hommes de l'entre-deux: Parcours individuels et portraits de groupes sur la frontière de la Méditerranée $X V I^{e}-X X^{e}$ siècle, edited by id. and Chantal Verdeil, 61-92. Paris: Les Indes savantes, 2009. 
—. Hindiyya, Mystic and Criminal, 1720-1798: A Political and Religious Crisis in Lebanon. Cambridge: James Clarke \& Co, 2013.

Howell, Jordan. "Book Abridgment in Eighteenth-Century England." Unpublished PhD diss, University of Delaware, 2017.

Ḥushayma, Kamīl. Al-Mu'allifūn al- 'arab al-masīhiyyūn min qabl al-islām ilā ākhir al-qarn al- 'ishrīn, vol. 2. Beirut: Dār al-Mashriq, 2011.

Hillebrand, Caspar. "Ottoman Travel Accounts to Europe: An Overview of Their Historical Development and a Commented Researchers' List." In Venturing beyond BordersReflections on Genre, Function and Boundaries in Middle Eastern Travel Writing, edited by Bekim Agai, Olcay Akyıldız and Caspar Hillebrand, 53-74. Würzburg: Ergon, 2013.

Jubāra, Ilyās. Al-Makhțūtāt al- 'arabiyya fì maktabat Batriyarkiyyat Anțākiya wa-sā'ir almashriq li-l-rūm al-urthūdhuks. Beirut: Markaz al-dirāsāt al-urthūdhuksī al-anțākī, 1988.

Khater, Akram Fouad. Embracing the Divine: Passion and Politics in the Christian Middle East. Syracuse: Syracuse University Press, 2011.

Kilpatrick, Hilary. "Between Ibn Batțūṭa and al-Ṭahțāwī: Arabic Travel Accounts of the Early Modern Period.” Middle Eastern Literatures 11 (2008): 233-248.

—. "Makāriyūs Ibn al-Za'īm (ca. 1600-1672) and Būlus Ibn al-Za'īm (Paul of Aleppo) (1627-1669)." In Essays in Arabic Literary Biography 1350-1850, edited by Joseph E. Lowry and Devin J. Stewart, 262-273.Wiesbaden: Harrassowitz, 2009.

Krimsti, Feras. Die Unruhen von 1850 in Aleppo: Gewalt im urbanen Raum. Berlin: Klaus Schwarz, 2014.

—. "The Lives and Afterlives of the Library of the Maronite Physician Hannā al-Ṭabīb (c. 1702-1775) from Aleppo.” Journal of Islamic Manuscripts 9 (2018): 190-217. 
Lammens, Henri [Hanrī Lāmins]. "Hayyā 'alā dars tārīkh bilādinā: șūrat tanẓ̄m jam iyya lidars al-tārīkh.” Al-Mashriq 1 (1898): 261-264.

Leeuwen, Richard van. Notables and Clergy in Mount Lebanon: The Khäzin Sheikhs and the Maronite Church (1736-1840). Leiden: Brill, 1994.

Louis XV. Ordonnance du Roi portant ce qui devra être observé par rapport aux Maronites \& autres Chrétiens orientaux, \& aux Esclaves rachetés qui se trouveront dans le royaume. Paris: Imprimerie Royale, 1753.

Marrāsh, Fransīs Fatḥallāh. Riḥlat Bārīs 1867, edited by Qāsim Wahb. Beirut: Mu'assasa al‘arabiyya li-1-dirāsāt wa-1-nashr, 2004.

Mörike, Tobias. "Lebanese Travellers as Knowledge Brokers in Early Modern Europe 1725 to 1800" (in preparation).

Moosa, Matti. The Maronites in History. Syracuse: Syracuse University Press, 1986.

Nichols, Stephen G. "Introduction: Philology in a Manuscript Culture,” Speculum 65.1 (1990): $1-10$.

Niebuhr, Carsten. C. Niebuhrs Reisebeschreibung nach Arabien und andern umliegenden Ländern, vol. 2. Kopenhagen: Hofbuchdruckerey bei Nicolaus Möller, 1778.

Pollock, Sheldon. "Future Philology? The Fate of a Soft Science in a Hard World." Critical Inquiry 35 (2009): 931-961.

Qar’alī, Būlus. “Al-Masīhịyyūn fī Ḥalab sanat 1748.” Al-Majalla al-batriyarkiyya 6 (1931): 361-370.

Rabbath, Antoine [Anțūn Rabbāṭ], ed. Riḥlat awwal sharqī ilā Amrika wa-hiya siyāhat al-khūrī Ilyās b. al-Qassīs Hannā al-Mawșilì min 'aylat bayt 'Ammūn al-Kildānī 1668-1683, Beirut: Al-Maṭba'a al-kāthūlīkiyya, 1906.

Rosenthal, Franz. The Technique and Approach of Muslim Scholarship. Rome: Pontificium Institutum Biblicum, 1947. 
Sajdi, Dana. The Barber of Damascus: Nouveau Literacy in the Eighteenth-Century Ottoman Levant, Stanford: Stanford University Press, 2013.

Sbath, Paul. Al-Fihris (Catalogue de Manuscrits Arabes), Deuxième Partie: Ouvrages des Auteurs des trois derniers siècles; Troisième Partie: Ouvrages Anonymes. Cairo: AlChark, 1939.

Seetzen, Ulrich Jasper. "Nachrichten von einigen Arabischen, Persischen und Türkischen Reisebeschreibungen, Topographien und andern geographischen Werken und Landkarten." Monatliche Correspondenz, zur Beförderung der Erd- und HimmelsKunde 12 (1805): 101-125.

—. "Nachricht von einigen arabischen Reiseberschreibungen und andern geographischen und topographischen Werken." Monatliche Correspondenz zur Beförderung der Erdund Himmels-Kunde 14 (1806): 25-40; I-III.

Taoutel, Ferdinand [Firdīnān Tawtil], ed. Wathā 'iq tārīkhiyya 'an Halab, vol. 1, Al-Hawādith wa-l-akhbār akhdhan 'an yawmiyyat Na' 'üm al-Bakhkhāsh (1855-1865) wa-ghayruhā min al-makhțūtāat. Beirut: Al-Maṭba a al-kāthūlīkiyya, 1940.

__ ed. “Al-Bațrīyark Isțifānūs al-Duwayhī: Tārīkh al-azmina 1095-1699.” Al-Mashriq 44 (1950): 1-440.

— , ed. "Riḥlat al-ab Arsāniyūs Shukrī Ārūtīn al-ḥakīm.” Al-Mashriq 61 (1967): 227-262; 325-356; 537-586; 62 (1968): 93-120.

Titz-Matuszak, Ingeborg. Mobilität der Armut: Das Almosenwesen im 17. und 18. Jahrhundert im südniedersächsischen Raum. Bovenden: Goltze, 1988.

Veinstein, Gilles. "Introduction." In Mehmed efendi, Le Paradis des infidèles: Relation de Yirmisekiz Çelebi Mehmed efendi, ambassadeur ottoman en France sous la Régence. Translated by J.-C. Galland, 7-51. Paris: Maspero, 1981.

Winet, Monika. "Religious Education on the Road: An Anonymous Christian Arabic Diary." Parole de l'Orient 39 (2014): 297-312. 